\title{
PARQUE ECOLÓGICO MONSENHOR EMÍLIO JOSÉ SALIM, CAMPINAS (SP): CONTRADIÇÕES NA IMPLEMENTAÇÃO DE UM PARQUE URBANO CONTEMPORÂNEO
}

\author{
ECHOLOGIC PARK MONSENHOR EMÍLIO JOSÉ SALIM, CAMPINAS (SP): \\ CONTRADICTIONS IN ESTABLISHING A CONTEMPORARY URBAN PARK
}

Daniela Andrade Lacreta*

Renata Baesso Pereira**

\section{RESUMO}

O presente artigo é resultado de uma pesquisa que buscou compreender os propósitos da administração pública, nas instâncias estadual e municipal, ao implantar, no final da década de 1980, o Parque Ecológico Monsenhor Emílio José Salim, na cidade de Campinas (SP). Projetado pelo escritório Burle Marx, sua implantação tinha por objetivo a revitalização de uma antiga fazenda, a recomposição da mata nativa em áreas ocupadas pelos cafezais e a restauração do casarão, exemplar relevante da arquitetura do período do café. Quadras esportivas, lanchonetes, mirante, restaurante, campos de futebol e áreas de passeio também estavam no escopo do projeto. Embora o parque já tenha passado por dois processos de tombamento - no nível estadual, pelo valor do seu conjunto arquitetônico, representativo da arquitetura cafeeira e, no nível municipal, por seu valor como parque urbano de concepção inovadora -, encontra-se atualmente sendo utilizado muito aquém do seu potencial como espaço público. Esta pesquisa também teve por objetivo traçar um diagnóstico que apresentasse os potenciais e as fragilidades desse equipamento urbano e diretrizes que pudessem auxiliar num possível processo de recuperação do parque.

Palavras-chave: Parques. Paisagem urbana. Espaços verdes. Arquitetura paisagística.

\footnotetext{
* Arquiteta e urbanista pela Pontifícia Universidade Católica de Campinas (PUC-Campinas). Especialista em Gerenciamento Ambiental pela Escola Superior de Agricultura Luiz de Queiroz da Universidade de São Paulo (ESALQ). Mestre em Urbanismo pelo Programa de Pós-Graduação em Urbanismo, Centro de Ciências Exatas, Ambientais e de Tecnologias (POSURB, CEATEC) da PUC-Campinas. Arquiteta paisagista, diretora da Nossa Flora Jardins (Projeto, manutenção e execução de jardins). Rua Dr. Miguel Penteado, 909, 13070-118, Jardim Chapadão, Campinas, SP, Brasil.

daniela.lacreta@gmail.com

** Arquiteta e urbanista pela Escola de Arquitetura da Universidade Federal de Minas Gerais (EA/ UFMG). Mestre em Urbanismo pelo Programa de Pós-Graduação em Urbanismo, Centro de Ciências Exatas, Ambientais e de Tecnologias (POSURB, CEATEC) da PUC-Campinas. Doutora em História e Fundamentos da Arquitetura e do Urbanismo pela Faculdade de Arquitetura e Urbanismo da Universidade de são Paulo (FAUUSP). Professora do POSURB/CEATEC, PUC-Campinas. Rodovia D. Pedro I, km 136, 13086-900, Parque das Universidades, Campinas, SP, Brasil.

renata.baesso@puc-campinas.edu.br
} 


\section{ABSTRACT}

This article is the result of a study that sought to understand the purposes of public administration on the state and municipal levels to deploy implant in the late 1980s, the Ecological Park Monsignor Emilio José Salim in the city of Campinas (SP). Designed by Burle Marx office, the implementation of the Ecological Park aimed to revitalize an old farm, restore native forests in areas occupied by coffee plantations and restore the main house, relevant example of the Coffee period architecture. Sports courts, coffee shops, gazebo, restaurant, soccer fields and walking areas were also in the project scope. Although the park is considered a heritage to be preserved - at the state level due to its architectural value (representative set of coffee architecture) and at the municipal level for its value as an innovative urban park design - its current use does not match its potential as a public space. The survey also aimed to outline a diagnosis that could show the potential and the weaknesses of this urban space, and could provide guidelines that can help in a possible recovery process of the park.

Keywords: Parks. Urban landscape. Green spaces. Landscape architecture (spaces).

\section{INTRODUÇÃO}

Observa-se hoje, no Brasil, diversos casos de parques públicos implantados de modo inadequado ou com problemas de gestão. A conscientização de que os parques devem ser valorizados, promovidos pelo poder público, respeitados e aproveitados pela população, está longe de ser ideal. Casos de depredação, invasão e descaso são observados em diversos parques urbanos pelo país. (MACEDO; SAKATA, 2003, p. 54). Seja por problemas relacionados ao projeto e programa, à localização e acessibilidade e principalmente à gestão, a verdade é que, embora tenha havido aumento quantitativo desses equipamentos, não se pode dizer o mesmo sobre a qualidade dos parques instalados.

À luz da literatura que investiga a produção de parques urbanos no Brasil, novos estudos de caso podem contribuir para avançar na discussão do tema. Este artigo apresenta, portanto, um estudo de caso do Parque Ecológico Monsenhor Emílio José Salim, localizado na região leste de Campinas (SP), às margens da rodovia Heitor Penteado, composto por 110 hectares de área. O parque foi inaugurado em 1991, em parte das terras da fazenda Mato Dentro, estabelecida como engenho de açúcar em 1806 pelo tenente-coronel Joaquim Aranha Barreto de Camargo. Na segunda metade do século XIX, o engenho é convertido em fazenda de café, destacando-se como uma das principais unidades produtoras da cidade. Com a crise do café, na década de 1930, parte da fazenda é vendida ao estado de São Paulo para a implantação do Instituto Biológico - IB (unidade de Campinas)'. A partir de então, os parcelamentos das áreas remanescentes da antiga fazenda Mato Dentro deram origem a diversos bairros na região leste de Campinas. No final da década de 1980, a Secretaria de Meio Ambiente do Estado de São Paulo (SMASP) promove a criação do Parque Ecológico Monsenhor

\footnotetext{
A fazenda Mato Dentro foi adquirida pelo Instituto Biológico do Estado de São Paulo em 1937, com o objetivo de desenvolver pesquisas de sanidade animal e vegetal por meio de criação de suínos, equinos e bovinos e campos experimentais de diversas culturas. Na mais recente reforma, a antiga Estação Experimental de Campinas passou a ser denominada Centro Experimental Central do Instituto Biológico (CEIB), localizado estrategicamente num polo de alta tecnologia, a cidade de Campinas. Disponível em: < http://www.biologico.sp.gov.br/ centro_experimental.php>. Acesso em: 16 jul. 2015.
} 
Parque Ecológico Monsenhor Emílio José Salim, Campinas (SP): Contradições na Implementação de um Parque Urbano Contemporâneo

Emílio José Salim em parte da área anteriormente adquirida para o Instituto Biológico. Projetado pelo escritório Burle Marx, sua implantação tinha por objetivo a revitalização da antiga fazenda, a recuperação de lagos e cascatas, a recomposição da mata nativa em áreas ocupadas pelos cafezais e a instalação de um programa de cultura nos edifícios remanescentes do complexo cafeeiro.

A pesquisa sobre a instalação do Parque Ecológico Monsenhor Emílio José Salim e sua relação com os processos fundiários envolvidos na conversão da antiga fazenda em loteamentos privados e área pública foi baseada em documentação primária, como cartografia histórica, inventários, escrituras e registros de venda de terras. Os processos de tombamento do parque pelo Conselho de Defesa do Patrimônio Cultural de Campinas (Condepacc) e da sede da antiga fazenda pelo Conselho de Defesa do Patrimônio Histórico, Arqueológico, Artístico e Turístico (Condephaat) foram documentos auxiliares da pesquisa. Para a análise do projeto paisagístico do parque, utilizou-se o projeto original, disponibilizado pelo Escritório Burle Marx.

\section{CAMPINAS E SEUS ESPAÇOS LIVRES PÚBLICOS}

Campinas nasceu de um pouso às margens do caminho aberto pelos paulistas em direção às "minas dos Goiases" na segunda metade do século XVIII. A região logo desenvolveu-se a partir da produção de açúcar, e após ser um bairro rural, pertencente à Vila de Jundiaí, em 1774 torna-se Freguesia de Nossa Senhora da Conceição das Campinas do Mato Dentro e, em 1797, Vila de São Carlos. A produção açucareira e, posteriormente, cafeeira da cidade logo enriqueceu algumas famílias donas de grandes fazendas, como a família Souza Aranha, dona da fazenda Mato Dentro, local onde foi instalado o Parque Ecológico Monsenhor Emílio José Salim na década de 1990

Graças ao prestígio do café, diversos melhoramentos urbanos foram implementados na cidade, que, embora tenham auxiliado o seu desenvolvimento, atendiam prioritariamente os interesses das famílias aristocráticas. Essa elite, portadora de diversos títulos imperiais, direcionou os investimentos para a valorização dos terrenos pertencentes às antigas sesmarias (SANTOS, 2002, p. 162) e para o "aformoseamento" da cidade, criando praças e jardins públicos. (LIMA, 2000, p. 31). Os jardins implantados na cidade modificaram sua dinâmica, mudando os costumes da população e impulsionando a "cultura" de jardins, que levou Campinas à notoriedade. (LIMA, 2000, p. 37).

Ao longo dos anos, intervenções com caráter saneador, como a de Saturnino de Brito no fim do século XIX, e alterações modernizadoras da cidade, durante os mandatos dos prefeitos Orozimbo Maia (1908-1910, 1926-1930, 1931-1932) e Heitor Penteado (1911-1920), trazem modificações importantes na tipologia de praças, jardins e avenidas. São instalados bulevares arborizados, os jardins públicos se abrem à cidade e as praças conectam-se às ruas, completamente arborizadas. (LIMA, 2000, p. 102).

Com a crise do café, a cidade até então agrária busca assumir uma fisionomia ligada à indústria e aos serviços. $\bigcirc$ crescimento intenso, gerado principalmente pela migração, tornou indispensável um plano urbanístico que direcionasse o desenvolvi- 
mento da cidade, e, em 1938, o urbanista Prestes Maia propõe um amplo conjunto de ações voltado a reordenar as vocações urbanas, a circulação e o crescimento de Campinas.

No plano, as antigas praças e jardins públicos tornam-se pontos importantes no processo de reestruturação e embelezamento da cidade. Prestes Maia traz para a cidade novo modelo paisagístico, similar ao proposto anteriormente para São Paulo e à luz dos preceitos do Movimento City Beautiful. Direcionando suas propostas principalmente para os problemas de circulação que a cidade já enfrentava, define espaços públicos - integrados ao que denomina sistema de áreas verdes - como pontos focais da reestruturação da cidade. Praças, jardins e parques integram-se como um sistema,

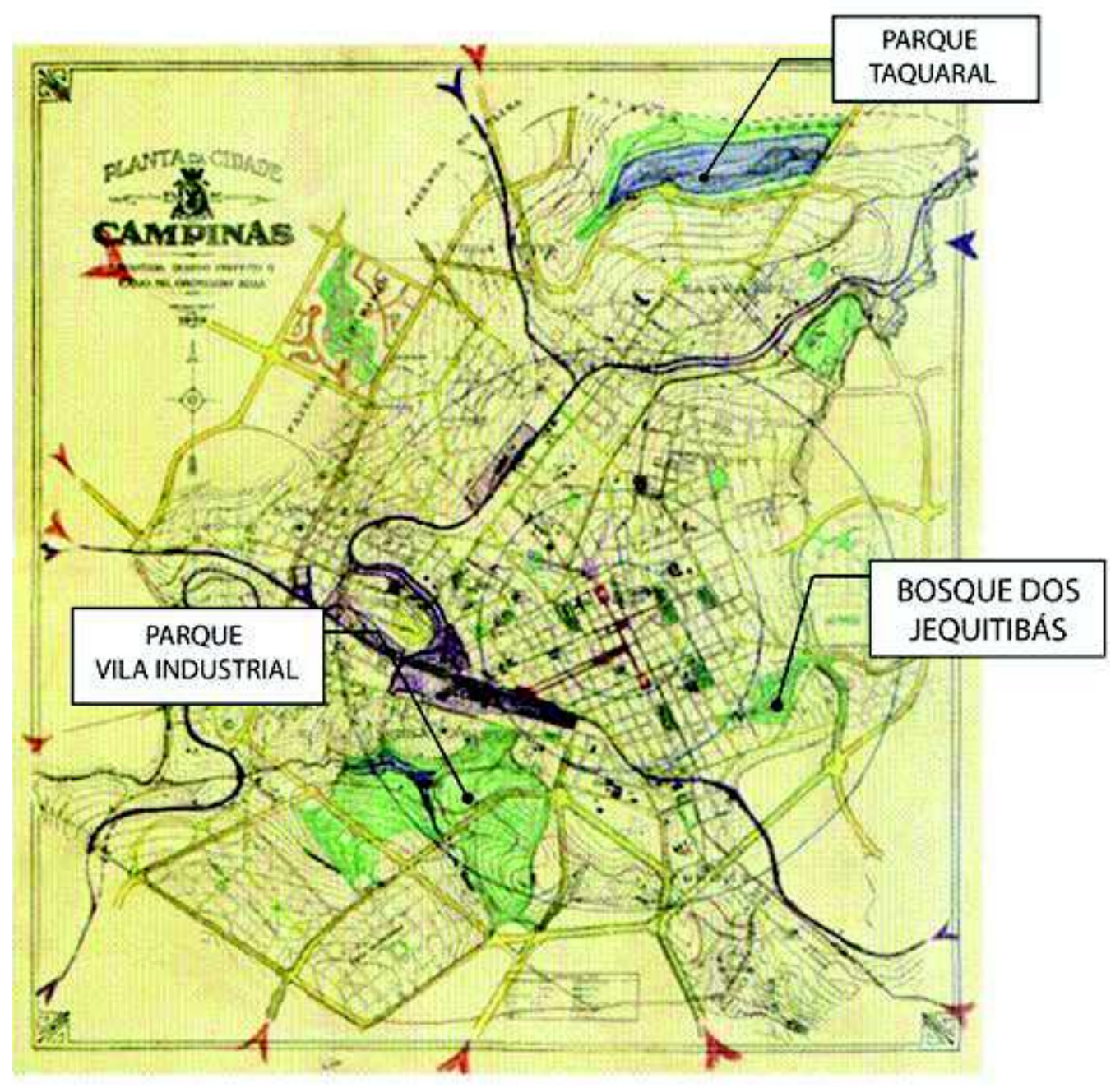

Figura 1 Sistema de parques no Plano de Remodelação da Cidade, de Prestes Maia, de 1829. Indicados os três principais parques da cidade, o parque da Vila Industrial nunca chegou a ser implantado. A planta apresenta anotações manuais assinadas por Prestes Maia. Documento apresentado por Luíz Cláudio Bittencourt, pertencente ao Arquivo da Câmara Municipal de Campinas.

Fonte: Bittencourt, 2002, p. 135. 
sendo os parques elementos fundamentais do modelo de Prestes Maia. $\bigcirc$ prefeito propõe, baseado nesses preceitos, a instalação de três parques. Com caráter regional, Prestes Maia cria o parque da Vila Industrial e o parque Portugal (Taquaral). O bosque dos Jequitibás, antiga área de lazer da cidade, seria reestruturado e transformado em parque para atender o centro da cidade. A proposta de Prestes Maia para Campinas pode ser avaliada na figura 1.

Embora Prestes Maia não tenha acompanhado a instalação de seu plano, suas propostas, parcialmente implantadas, nortearam as mudanças promovidas pela prefeitura municipal nas décadas de 1930 e 1940, influenciando modificações na cidade nas décadas seguintes. (LIMA, 2000, p. 124). Novas avenidas foram criadas, assim como as perimetrais, o parque Taquaral foi instalado e o bosque dos Jequitibás reformado. Já o parque da Vila Industrial, justamente o que atenderia a uma região mais necessitada, nunca saiu do papel. Ao ser instalado, o parque Taquaral valorizou essa região da cidade, onde foram lançados loteamentos de alto padrão. Tal área tornou-se, na década de 1970, nova centralidade para a cidade, e o parque, de proporções modestas para a quantidade de indivíduos que o frequentam, é o mais utilizado da cidade atualmente.

A grande expansão industrial e populacional ocorrida na década de 1970 dá início a um grande parcelamento do solo, seguido pela criação de novos loteamentos em regiões cada vez mais dispersas e distantes do centro da cidade. A cidade, que na década de 1960 ocupava área de aproximadamente 76 mil quilômetros quadrados, passa a ocupar, em 1978, mais de 150 mil quilômetros quadrados. (PREFEITURA DE CAMPINAS, 1991).

Parte da região leste de Campinas, onde se encontra o Parque Ecológico Monsenhor Emílio José Salim, desenvolve-se a partir do parcelamento da antiga fazenda Mato Dentro ${ }^{2}$, como pode ser verificado na figura 2. Embora pouco urbanizada até a década de 1990, a região leste possui, atualmente, a maior concentração de condomínios horizontais e loteamentos fechados de alto padrão da cidade.

Na tabela 1, é possível verificar (em negrito) dados de 1991, referentes à renda média mensal nominal dos chefes de família moradores da região leste de Campinas, onde se localiza o Parque Ecológico Monsenhor Emílio José Salim. Pode-se observar como a renda média mensal (em salários mínimos) da região é muito maior do que as relacionadas a demais áreas da cidade.

\footnotetext{
Conforme documentação levantada, a fazenda, inicialmente formada como engenho e plantação de cana-de-açúcar, data de 1806, originada a partir de uma gleba de terra desdobrada de uma sesmaria pelo tenente- coronel Joaquim Aranha Barreto de Camargo. Segundo Silva (2006), um dos primeiros bairros registrados em Campinas foi Mato Dentro, citado em documento de 14/7/1774 como a área onde se localizava o engenho de mesmo nome. Era um exemplar da ocupação fundiária e da produção agrícola da região no final do século XVIII. A fazenda passa por desmembramentos que geram duas novas fazendas, a Mato Dentro de Baixo e a Brandina. Essas novas fazendas foram posteriormente parceladas e transformadas em bairros: a Mato Dentro de Baixo no bairro Vila Brandina, a fazenda Lapa no bairro das Palmeiras e o Clube Sociedade Hípica de Campinas. Com a crise de 1930 e a queda da comercialização do café nos mercados internacionais, a fazenda foi vendida, em 1937, para o Governo do Estado de São Paulo, que a transformou na Estação Experimental do Instituto Biológico de Campinas, abrigando laboratórios, residências de pesquisadores e trabalhadores e pesquisas de novas culturas.
} 


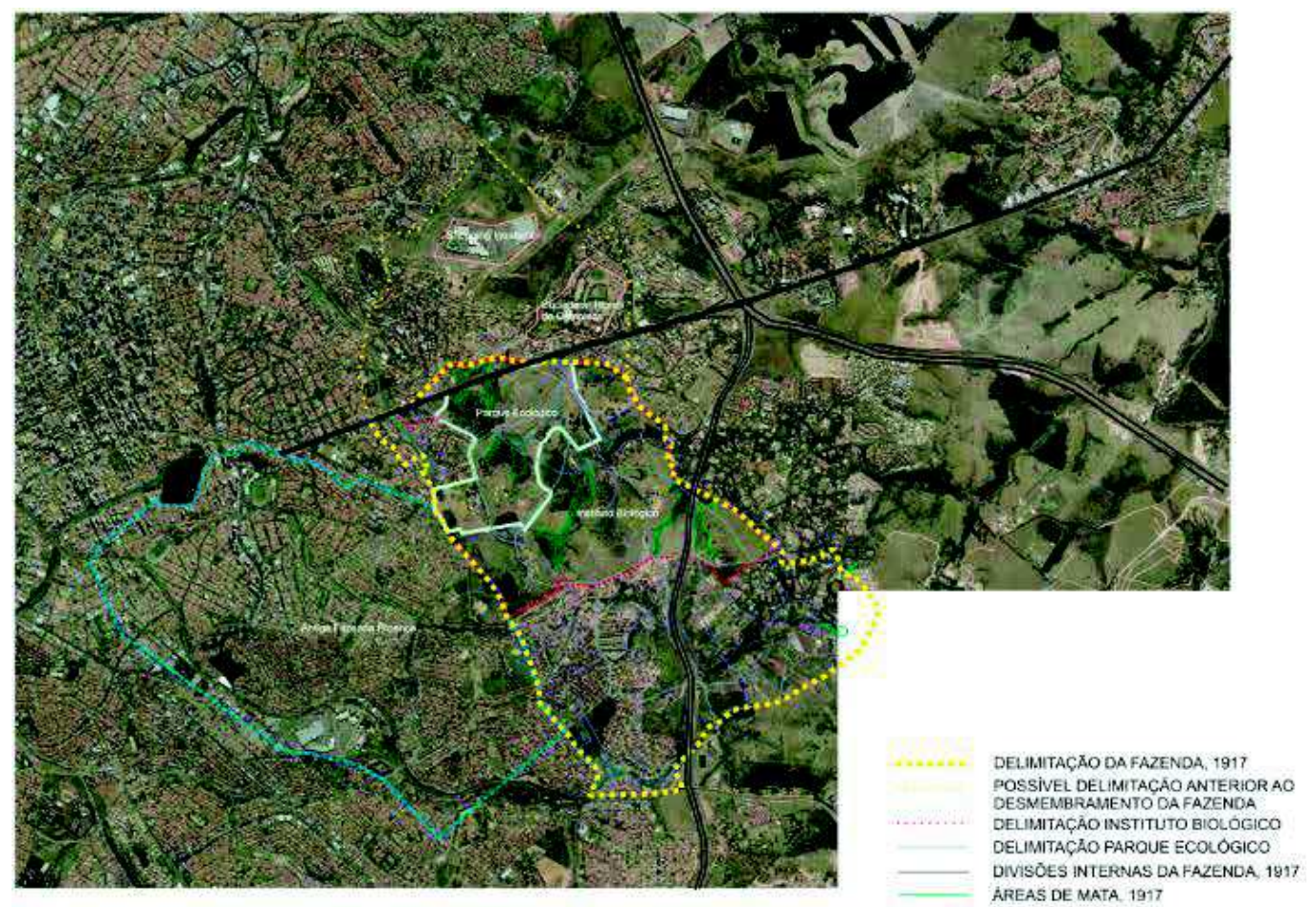

Figura 2 Parcelamentos da antiga fazenda Mato Dentro, localização do Parque Ecológico Monsenhor Emílio José Salim, do Instituto Biológico e principais rodovias.

Fonte: Imagem elaborada pela autora a partir de foto aérea do Google.

Tabela 1 Renda Média Mensal Nominal do Chefe da Família

\begin{tabular}{c|c}
\hline \multicolumn{2}{c}{$\begin{array}{c}\text { Renda Média Mensal Nominal do Chefe da Família } \\
\text { Município de Campinas - 1991 }\end{array}$} \\
\hline $\begin{array}{c}\text { D.R.O. Diretório Regional } \\
\text { de Operações }\end{array}$ & $\begin{array}{c}\text { Renda Média Mensal } \\
\text { (em salários mínimos) }\end{array}$ \\
\hline Norte & 7,32 \\
\hline Sul & 5,99 \\
\hline Leste & $\mathbf{1 1 , 0 2}$ \\
\hline Sudoeste & 4,21 \\
\hline Noroeste & 3,76 \\
\hline
\end{tabular}

Fonte: Instituto Brasileiro de Geografia e Estatística (IBGE), Censo Demográfico de 1991. Sistematização dos dados: Secretaria de Planejamento, Departamento de Planejamento e Desenvolvimento Urbano de Campinas (p. 36). Sumário de Dados - População Campinas e Região, 1998.

Na tabela 2, observa-se que a taxa de crescimento da região leste, onde se encontra - Parque Ecológico, teve o maior crescimento da cidade na década de 1980, o que comprova as informações apresentadas na figura 1. 
Parque Ecológico Monsenhor Emílio José Salim, Campinas (SP): Contradições na Implementação de um Parque Urbano Contemporâneo

Tabela 2 Taxa de Crescimento da População - Anos 1970, 1980, 1991 e 1996

\begin{tabular}{|c|c|c|c|c|c|c|c|c|c|c|c|}
\hline \multirow{3}{*}{ D.R.o. } & \multicolumn{6}{|c|}{ População } & \multirow{2}{*}{\multicolumn{2}{|c|}{$\frac{\text { Grau de Urbanização \% }}{\text { Total }}$}} & \multirow{2}{*}{\multicolumn{3}{|c|}{$\begin{array}{c}\text { Taxas de Crescimento (\% aa..) } \\
1991-1996\end{array}$}} \\
\hline & \multicolumn{2}{|c|}{ Total } & \multicolumn{2}{|c|}{ Urbana } & \multicolumn{2}{|c|}{ Rural } & & & & & \\
\hline & 1991 & 1996 & 1991 & 1996 & 1991 & 1996 & 1991 & 1996 & Total & Urbana & Rural \\
\hline Leste & 207.047 & 209.229 & 201.746 & 204.500 & 5.301 & 4.729 & 97,44 & 97,74 & 0,21 & 0,27 & $-2,26$ \\
\hline Sul & 223.480 & 228.434 & 218.812 & 223.446 & 4.668 & 4.988 & 97,91 & 97,82 & 0,44 & 0,42 & 1,33 \\
\hline Norte & 163.293 & 163.848 & 158.026 & 158.731 & 5.267 & 5.117 & 96,77 & 96,88 & 0,07 & 0,09 & $-0,58$ \\
\hline Sudoeste & 180.339 & 217.696 & 177.331 & 206.291 & 3.008 & 11.405 & 98,33 & 94,76 & 3,84 & 3,07 & 30,55 \\
\hline Noroeste & 73.128 & 88.547 & 68.701 & 85.975 & 4.427 & 2.572 & 93,95 & 97,10 & 3,90 & 4,59 & $-10,29$ \\
\hline Total & 847.287 & 907.754 & 824.616 & 878.943 & 22.671 & 28.811 & 97,32 & 96,83 & 1,39 & 1,28 & 4,91 \\
\hline
\end{tabular}

Fonte: IBGE, Censo Demográfico de 1991. Sistematização dos dados: Secretaria de Planejamento - Departamento de Planejamento e Desenvolvimento Urbano. Disponível em: <http://www.campinas.sp.gov.br/governo/seplama/ publicacoes/sumario-dados-demograficos.php>. Acesso em: 23 jun. 2015.

Na figura 3, o mapa de crescimento urbano apresentado pela Secretaria Municipal de Planejamento e Desenvolvimento Urbano (Seplan) da Prefeitura de Campinas no Plano Diretor de 2006, demonstra que o crescimento urbano no seu entorno imediato se deu, basicamente, na década de 1980; nota-se crescimento também na década de 1990, (mesma década da instalação do Parque Ecológico).

Já o mapa da figura 4, desenvolvido juntamente com o mapa da figura 3 mostra que, embora os lotes no entorno do parque tenham sido aprovados décadas antes com uma área aprovada na década de 1950 e outra na década de 1970 -, somente a partir da década de 1980 essa região começa a abrigar novas residências.

Por fim, na figura 5, também parte do Plano Diretor de 2006, o entorno do Parque Ecológico Monsenhor Emílio José Salim encontra-se circulado em verde. Pode-se observar a maior concentração de alta renda da cidade (vinte salários mínimos ou mais). Ao sul do parque, onde se encontra a segunda portaria, são identificados focos de habitação com rendas médias abaixo de cinco salários mínimos. A única barreira entre essas duas regiões é o parque.

Em 1990, Campinas contava com área urbanizada de aproximadamente 200 quilômetros quadrados. Segundo o Plano Diretor (2006) do município, 460 hectares eram de áreas verdes urbanizadas, incluindo jardins, parques e praças, porém, nas regiões mais periféricas e carentes da cidade, não foi identificada nenhuma área verde.

As propostas do Plano de Prestes Maia para a instalação de parques de caráter regional ficaram pendentes nas administrações públicas seguintes. Somente com a instalação do Parque Ecológico Monsenhor Emílio José Salim - quase quarenta anos depois -, é que um novo parque, nas proporções pretendidas no Plano de Prestes Maia, propõe-se a cumprir esse papel. No final da década de 1990, Campinas contava com poucos parques capazes de atender a demanda da cidade, e os existentes encontravam-se na área mais central nesse período. Os principais parques utilizados eram os seguintes: 
- Bosque dos Jequitibás - $101.000 \mathrm{~m}^{2}$ (1915);

- Parque Portugal (Taquaral) - $638.000 \mathrm{~m}^{2}$ (1972);

- Bosque dos Guaratãs - $100.000 \mathrm{~m}^{2}$ - sem data indicada;

- Parque Valença - $88.471 \mathrm{~m}^{2}$ - sem data indicada;

- Parque Ecológico (estadual) - 1.100.000 m² (1987).

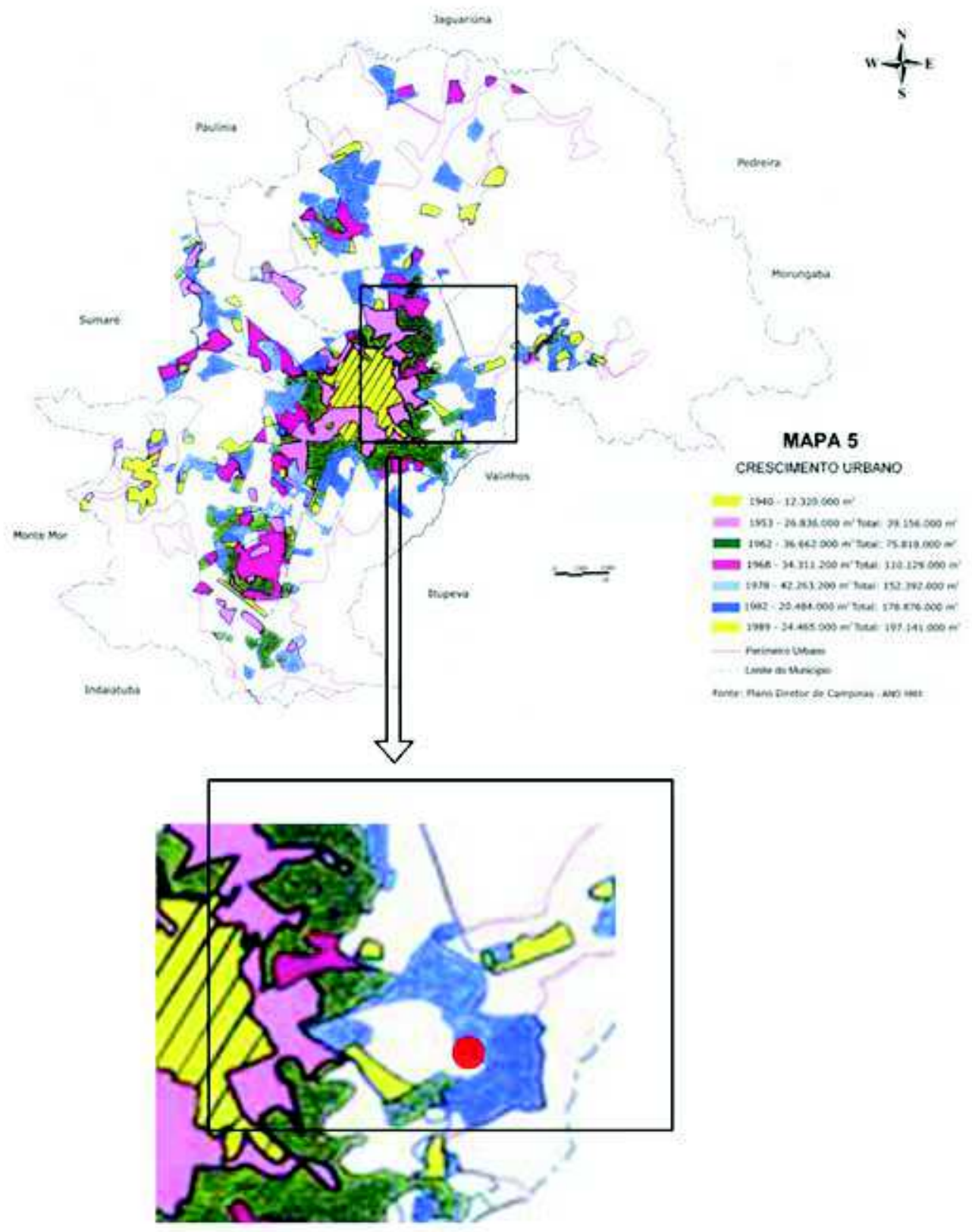

Figura 3 Mapa do crescimento urbano. Em vermelho, a área aproximada do Parque Ecológico. Fonte: Secretaria Municipal de Planejamento e Desenvolvimento Urbano (Seplan) da Prefeitura Municipal de Campinas. Disponível em: <http://www.campinas.sp.gov.br/governo/seplama/publicacoes/planodiretor2006/mapas/mapa5.jpg>. Acesso em: 23 jun. 2015. 
Parque Ecológico Monsenhor Emílio José Salim, Campinas (SP): Contradições na Implementação de um Parque Urbano Contemporâneo

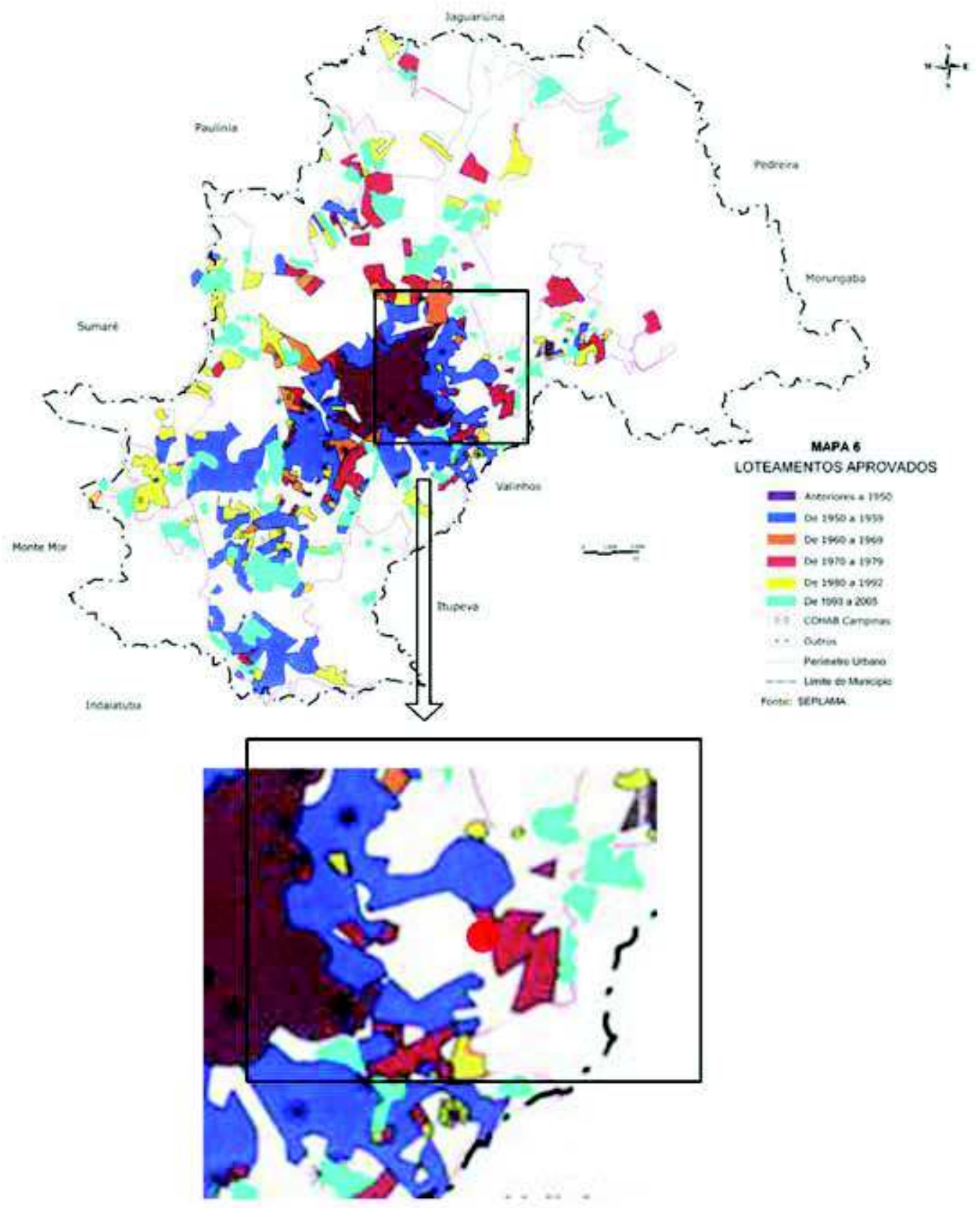

Figura 4 Mapa com os loteamentos aprovados por décadas. Em vermelho, a área aproximada do Parque Ecológico. Fonte: Secretaria Municipal de Planejamento e Desenvolvimento Urbano (Seplan) da Prefeitura Municipal de Campinas. Disponível em: <http://www.campinas.sp.gov.br/governo/seplama/publicacoes/planodiretor2006/ mapas/mapa6.jpg >. Acesso em: 23 jun. 2015. 

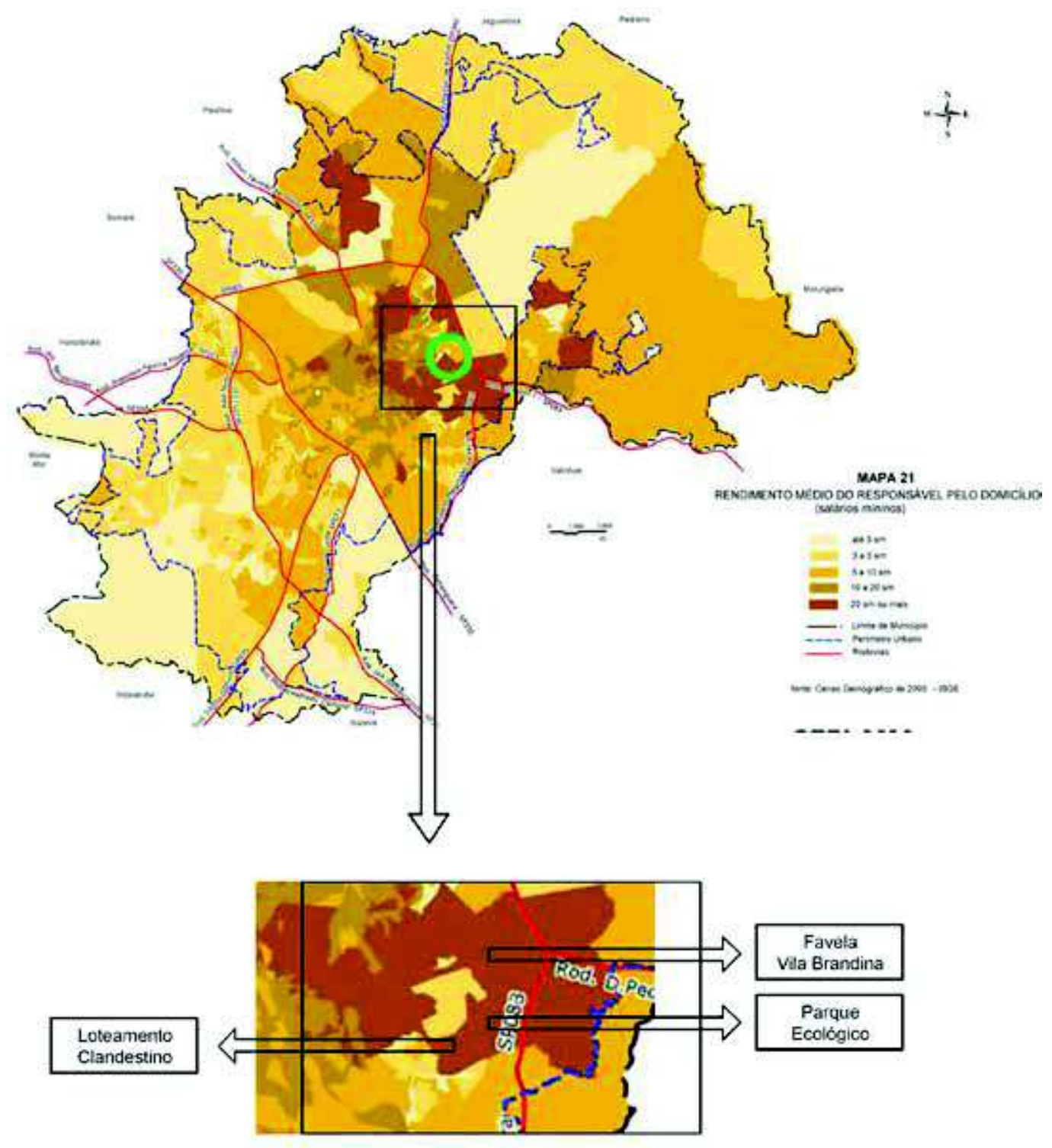

Figura 5 Mapa representando a renda média do responsável pelo domicílio em 1991. Fonte: Secretaria Municipal de Planejamento e Desenvolvimento Urbano (Seplan) da Prefeitura Municipal de Campinas, a partir de dados do censo de 1991 do IBGE. Disponível em: <http://www.campinas.sp.gov.br/governo/seplama/publicacoes/ planodiretor2006/mapas/mapa21.jpg >. Acesso em: 23 jun. 2015.

A partir dessa lista, pode-se observar como a área do Parque Ecológico Monsenhor Emílio José Salim é maior do que a soma das áreas de todos os outros parques juntos. Foi implantado num momento em que, principalmente o parque Portugal e o bosque dos Jequitibás, estavam no limite de saturação, por atenderem toda a cidade.

A figura 6 mostra em sua legenda, entre outros, os três principais parques da cidade: - Parque Ecológico Monsenhor Emílio José Salim ( $\left.n^{\circ} 17\right)$, o Parque Portugal $\left(n^{\circ} 16\right)$ e - Bosque dos Jequitibás ( $n^{\circ}$ 8). Fica visível a diferença de tamanho destes em relação ao Parque Ecológico. 


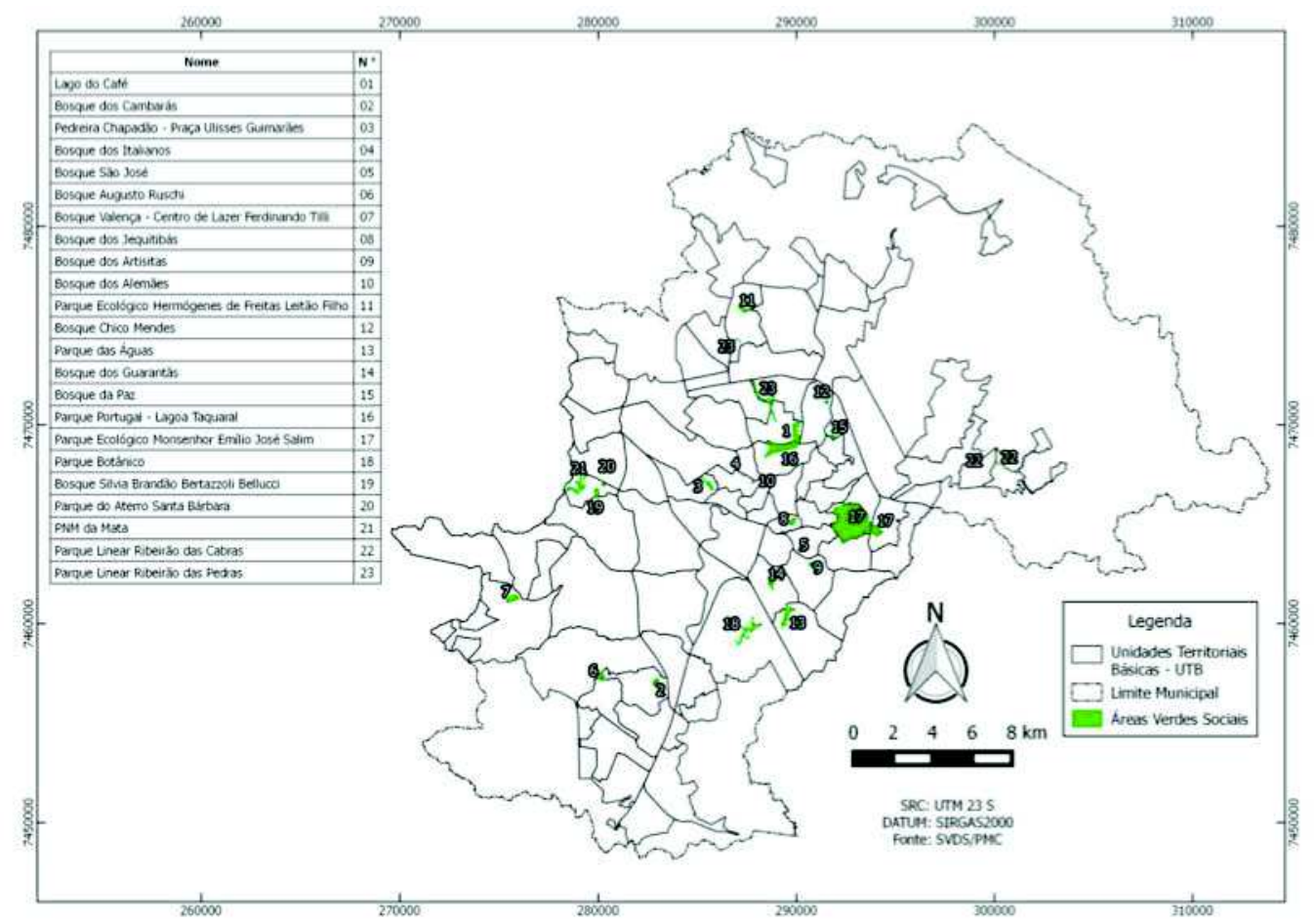

Figura 6 Principais áreas verdes de Campinas segundo diagnóstico feito pela Prefeitura Municipal de Campinas em 2015. Fonte: Diagnóstico Preliminar SDVS/PMC, 2015. Disponível em: <http://campinas.sp.gov.br/arquivos/meioambiente/diagnostico_preliminar.pdf >. Acesso em: 23 jun. 2015.

\section{O PROCESSO DE PROMOÇÃO E INSTALAÇÃO DO PARQUE ECOLÓGICO MONSENHOR EMÍLIO JOSÉ SALIM}

O Governo do Estado de São Paulo foi quem propôs o Parque Ecológico Monsenhor Emílio José Salim para atender às demandas da cidade por um novo equipamento de lazer e área verde. Ocupando 110 hectares de parte da área total de 285 hectares do Instituto Biológico, foi implantado na área da antiga fazenda Mato Dentro, abrangendo o conjunto histórico composto pela casa sede e tulha, tombados pelo Condephaat ${ }^{3}$. O projeto foi desenvolvido pelo Escritório Burle Marx, e entre seus principais atrativos estavam a implantação de um Arboretum com espécies nativas, a revitalização de um lago, a transformação do estábulo em restaurante e da tulha em "café-concerto". Seriam também instaladas quadras poliesportivas, um mirante, campos de futebol, áreas de estar, área para piquenique, churrasco e um teatro de arena.

$\mathrm{Na}$ antiga casa sede, completamente restaurada, foi instalado o Centro Integrado de Percepção Ambiental (CIPAM), que tinha como propósito "[...] estimular de maneira inovadora e atraente a percepção do meio ambiente e das intervenções socioeconômicas e culturais na qualidade de vida [...]". (Cetesb,1990). Para tanto, dividia-se em quatro eixos: cultura e meio ambiente, cosmos, biodiversidade e polvição.

3 Processo de tombamento número 00309/73 de 1982. 
A obra foi dividida em três etapas, sendo a principal o projeto de restauro do casarão sede da fazenda Mato Dentro, de 1810. A ideia não era somente restaurar o casarão com detalhes da época, mas também transformá-lo num museu capaz de resgatar a história de Campinas ligada ao ciclo do café 4 . Para o projeto de recuperação da paisagem da antiga fazenda, foram revitalizados os cursos d'água existentes para formação de lagos e cascatas. Havia, também, a proposta de recuperação da mata nativa, anterior ao plantio do café, mediante a instalação de trezentas espécies características da região de Campinas.

O acesso à portaria principal do parque se dá pela rodovia Heitor Penteado - importante ligação entre o centro da cidade e os distritos de Sousas e Joaquim Egídio, acesso à rodovia Dom Pedro I e ao anel viário Magalhães Teixeira. Um estacionamento para aproximadamente quatrocentros carros fica logo à direita assim que se adentra o parque, e a poucos passos encontra-se o lago - rodeado por palmeiras enfileiradas -, o antigo estábulo, transformado em restaurante, o novo edifício do ripado, um espaço para exercícios e a administração. Num plano mais alto, à esquerda, uma longa ladeira arborizada chega ao portão de entrada do antigo casarão, sede do CIPAM. No tempo em que a fazenda era produtiva, observava-se todo o território da varanda da casa sede. Ao lado desta há uma pequena capela - e logo atrás, a tulha, entre árvores antigas e um jardim.

Voltando ao lago, seguindo em direção oposta, um extenso caminho sinuoso e íngreme leva o visitante à área de lazer ativo, onde estão localizadas as quadras poliesportivas. Ao longo desse caminho, trilhas secundárias formam-se, terminando em pátios projetados para festas, piqueniques e churrascos. Das quadras poliesportivas, pode-se ver todo o parque abaixo; bem próximo, encontra-se o mirante. Nessa área também ficam um teatro de arena, alguns sanitários e lanchonetes, instalados em edifícios simples e rústicos.

Cortando toda a porção oeste do parque - onde estão os dois campos de futebol, o edifício da bocha, outra portaria e outro estacionamento, bem no coração de um bairro residencial - uma avenida dá acesso a um edifício da Sociedade de Abastecimento de Água e Saneamento S/A de Campinas (Sanasa) ${ }^{5}$. $O$ acesso para a outra parte do parque é feito sob dois pontilhões. A característica mais marcante do paisagismo são os maciços de árvores e, principalmente, as palmeiras de diversas espécies, distribuídas em linhas sinuosas e imponentes, ou em maciços desenhados. Os caminhos e pátios, também sinuosos, são característicos do traço de Roberto Burle Marx. A vegetação utilizada é uma seleção de plantas nativas com plantas comuns da região e espécies exóticas. As plantas de grande porte e o verde tomam conta da paisagem; não existem muitos canteiros de forrações, nem variedades de cores comuns nos projetos do paisagista.

Antigo casarão da "Mato Dentro" será restaurado. Correio Popular, Campinas, 24 de setembro de 1988.

Empresa responsável pelo abastecimento de água (captação, adução, tratamento, reserva e distribuição de água potável), coleta, afastamento e tratamento dos esgotos domésticos no município de Campinas. 
Parque Ecológico Monsenhor Emílio José Salim, Campinas (SP): Contradições na Implementação de um Parque Urbano Contemporâneo

A figura 7 exibe a perspectiva em desenho do Parque Ecológico (apresentado em prospecto distribuído na época da inauguração do mesmo). $\bigcirc$ desenho mostra a abundância vegetal e a sinuosidade características dos projetos de Burle Marx. O lago sinuoso, com linhas marcadas por palmeiras imponentes, torna-se o objeto central desse projeto.
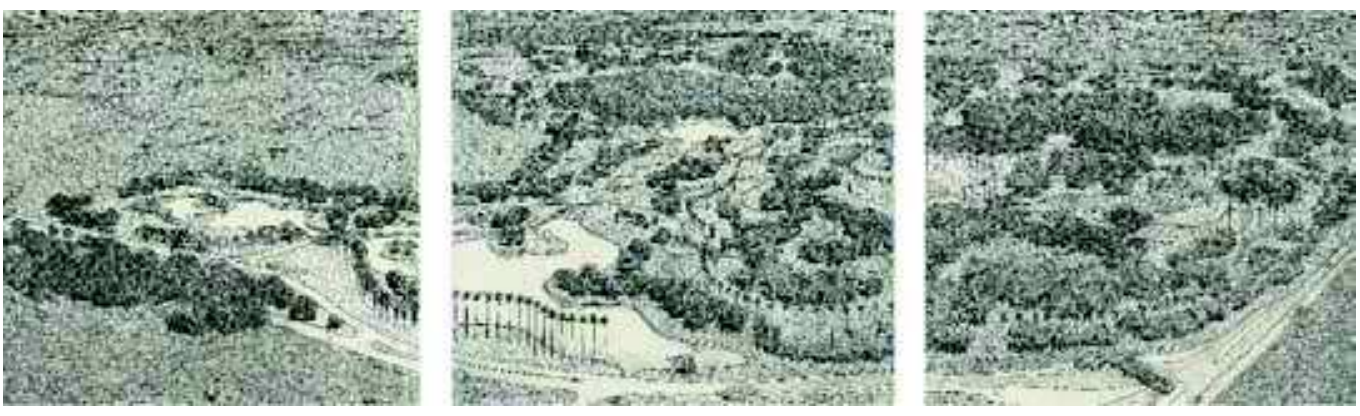

Figura 7 Croqui do projeto paisagístico. Fonte: Prospecto distribuído pela Companhia Ambiental do Estado de São Paulo (Cetesb) na inauguração do Parque Ecológico. Projeto gráfico e desenho: Vallandro Keating, 1990.

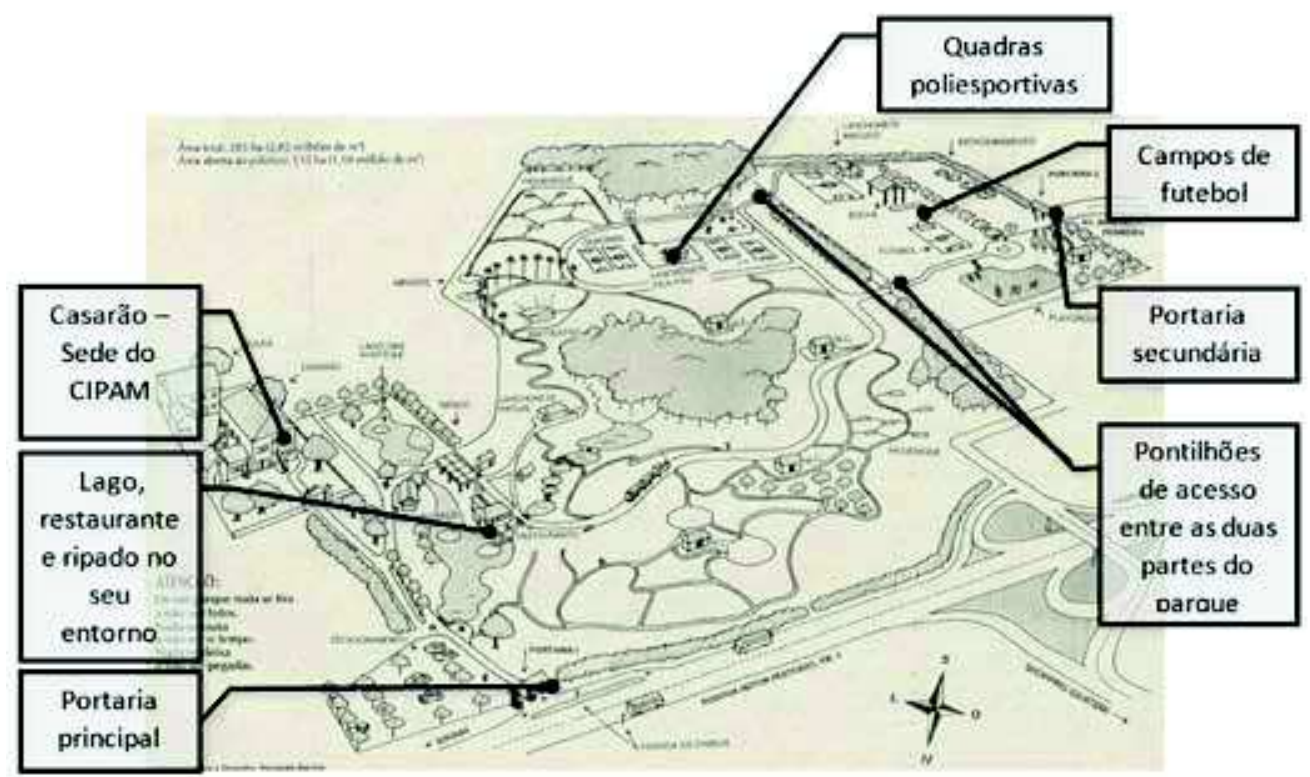

Figura 8 Perspectiva do parque com seus principais equipamentos em fôlder promocional fornecido pelo Governo do Estado de São Paulo (gestão Orestes Quércia). Fonte: Prospecto distribuído pela Companhia Ambiental do Estado de São Paulo (Cetesb) na inauguração do Parque Ecológico. Projeto gráfico e desenho: Fernando Barreto, 1990.

Também partes do prospecto, as figuras 8 a 12 apresentam os diversos atrativos do Parque Ecológico. Na figura 9, a antiga casa sede, completamente restaurada, abrigou - CIPAM durante um período, onde eram proporcionadas ações educativas visando à manutenção do meio ambiente. A figura 10 apresenta o antigo estábulo, reformado e transformado em restaurante para duzentas pessoas, e a figura 12 apresenta o Ripado 
- estrutura aberta em aço e vigas de eucalipto tratado, para exposições de plantas e venda de produtos ecológicos. Esse espaço foi o único novo edifício proposto para o parque e seria responsável por abrigar feiras e exposições.

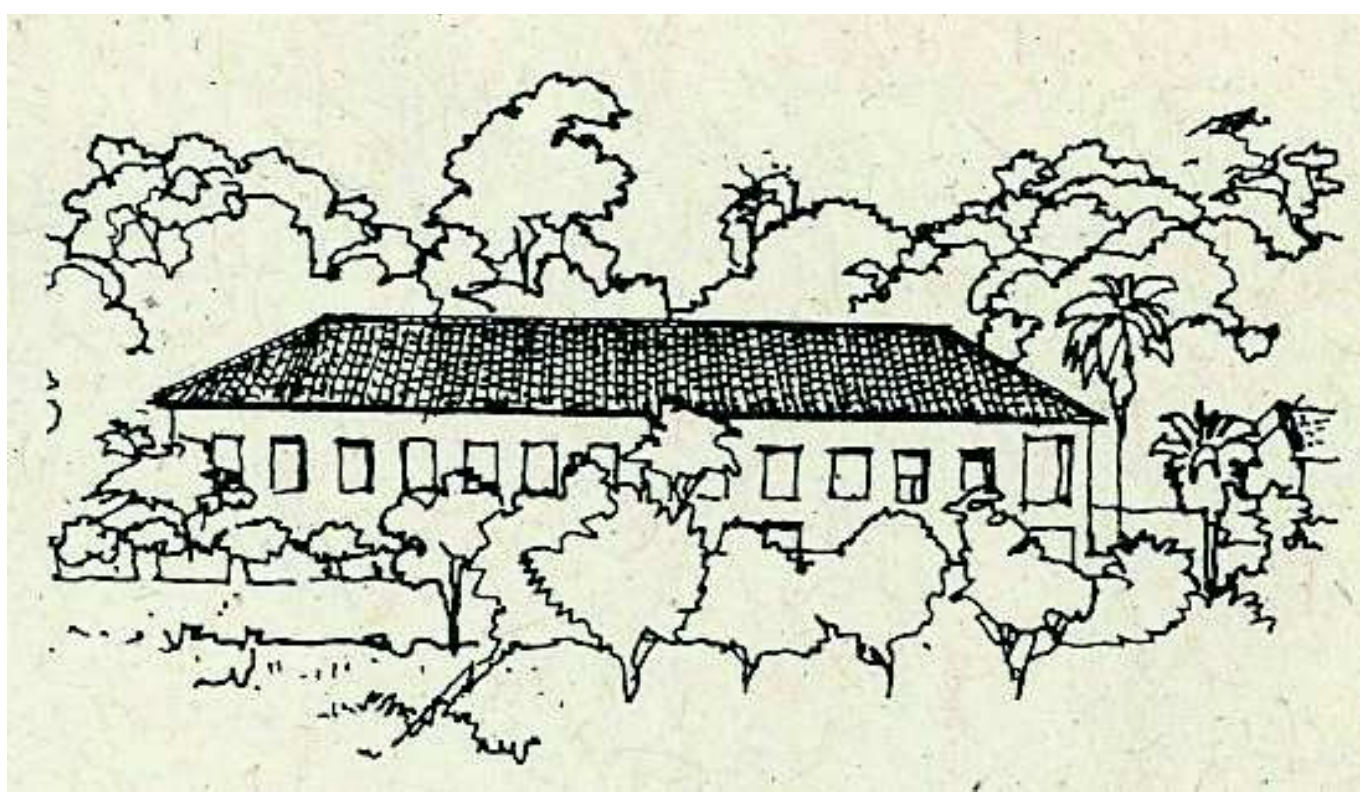

Figura 9 Casarão, sede do Centro de Percepção Ambiental (CIPAM). Fonte: Cetesb. Desenho: Vallandro Keating, 1990.

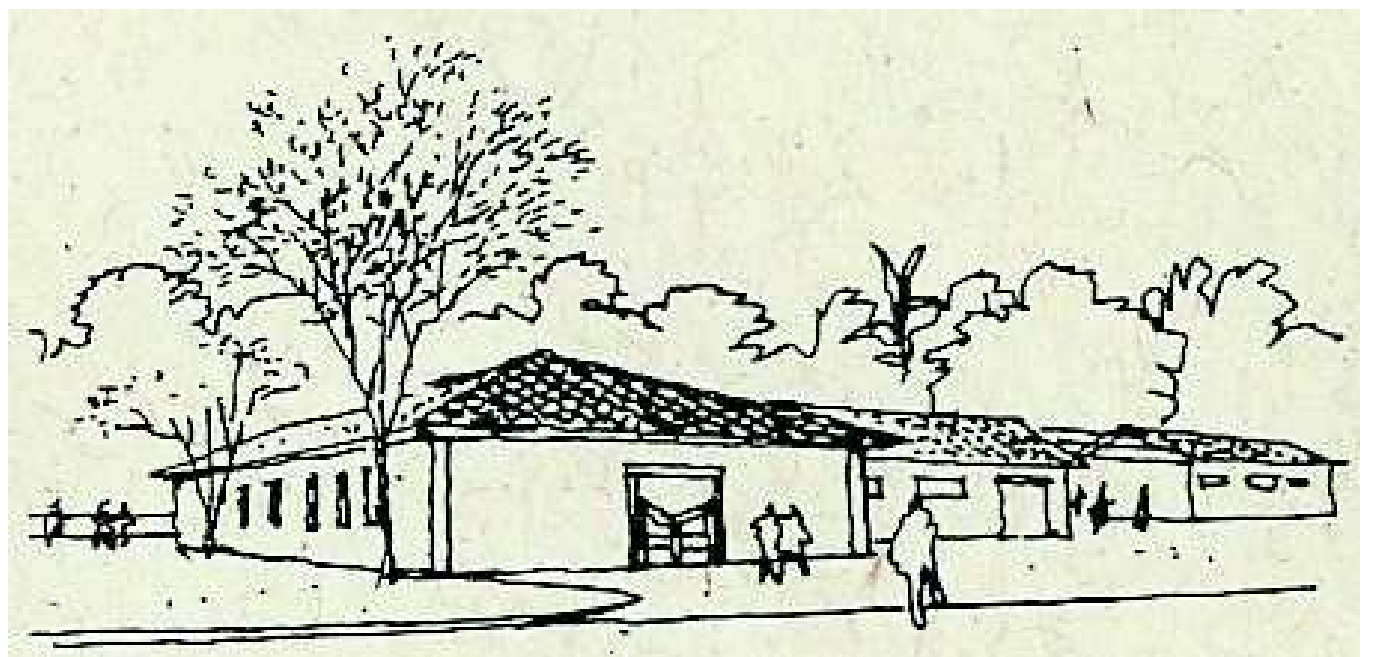

Figura 10 Antigo estábulo da fazenda.

Fonte: Cetesb. Desenho: Vallandro Keating, 1990. 


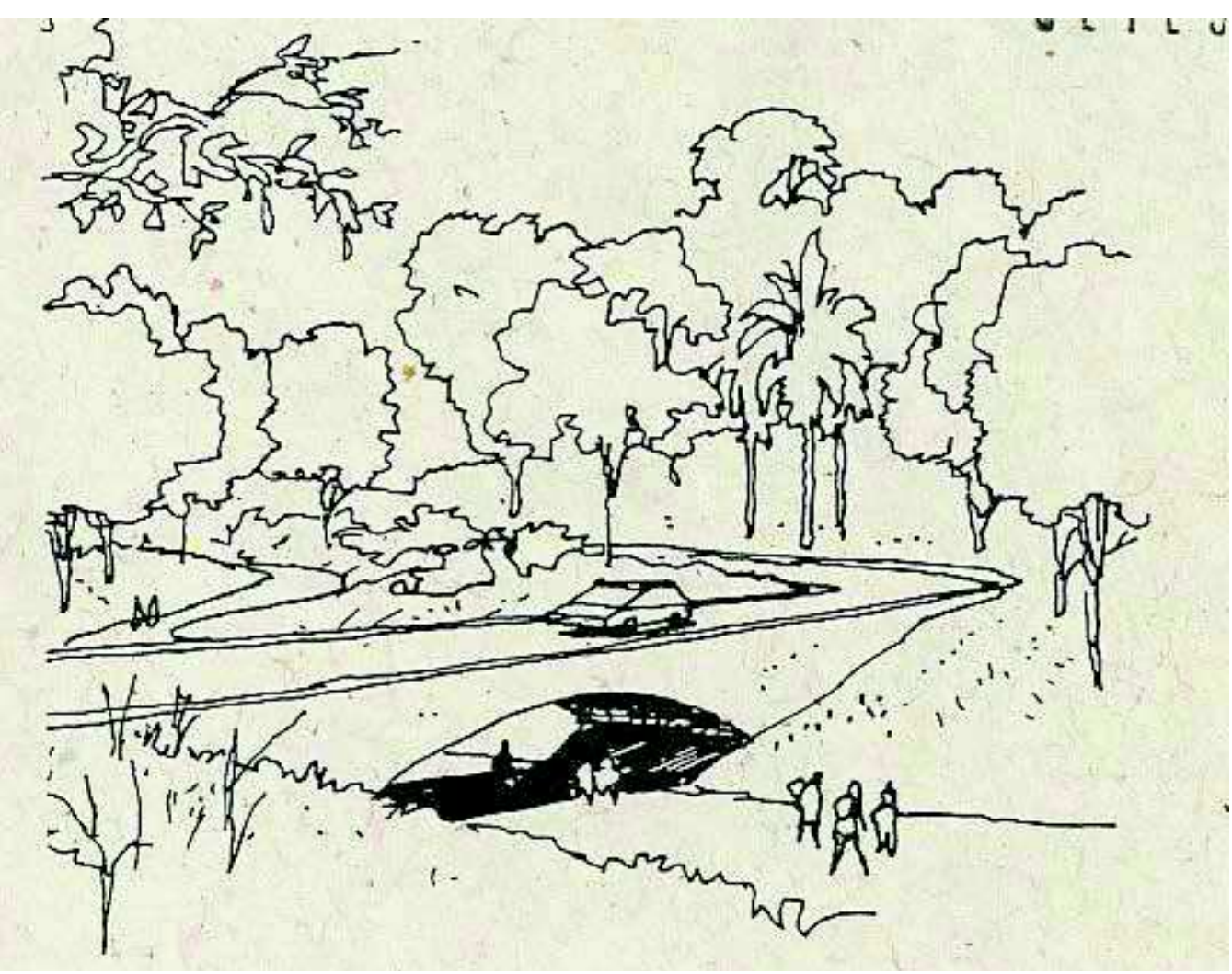

Figura 11 Pontilhão de ligação entre as duas partes do parque.

Fonte: Cetesb. Desenho: Vallandro Keating, 1990.

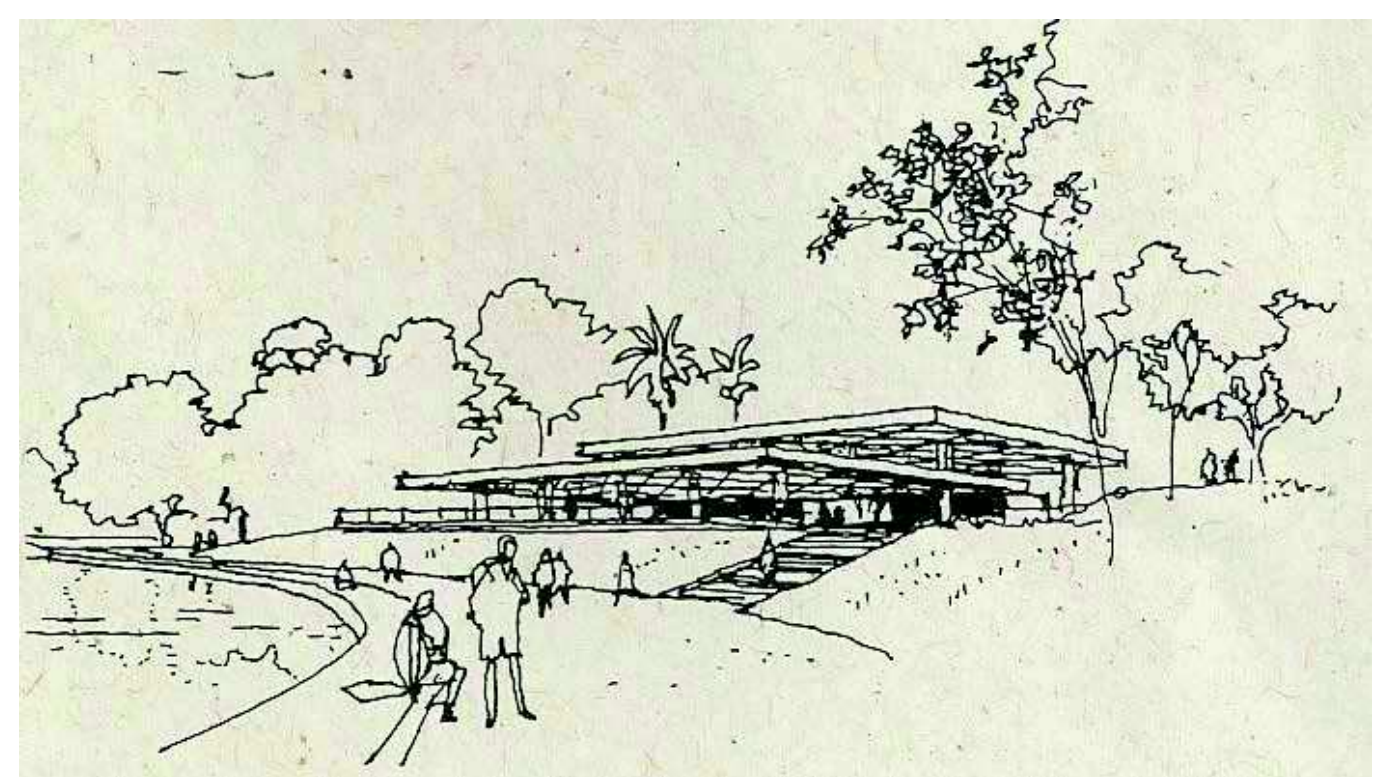

Figura 12 Ripado.

Fonte: Cetesb. Desenho de Vallandro Keating, 1990. 
Na montagem (figura 13) feita com o projeto paisagístico original sobre foto aérea de 2015 da cidade de Campinas, podemos ver a leste do parque sua divisa com o Instituto Biológico, e a oeste os diversos condomínios de alto padrão. A figura 14 apresenta o projeto paisagístico original fornecido pelo Escritório Burle Marx em uma prancha com detalhe do paisagismo do complexo arquitetônico tombado (casa sede, tulha e capela).

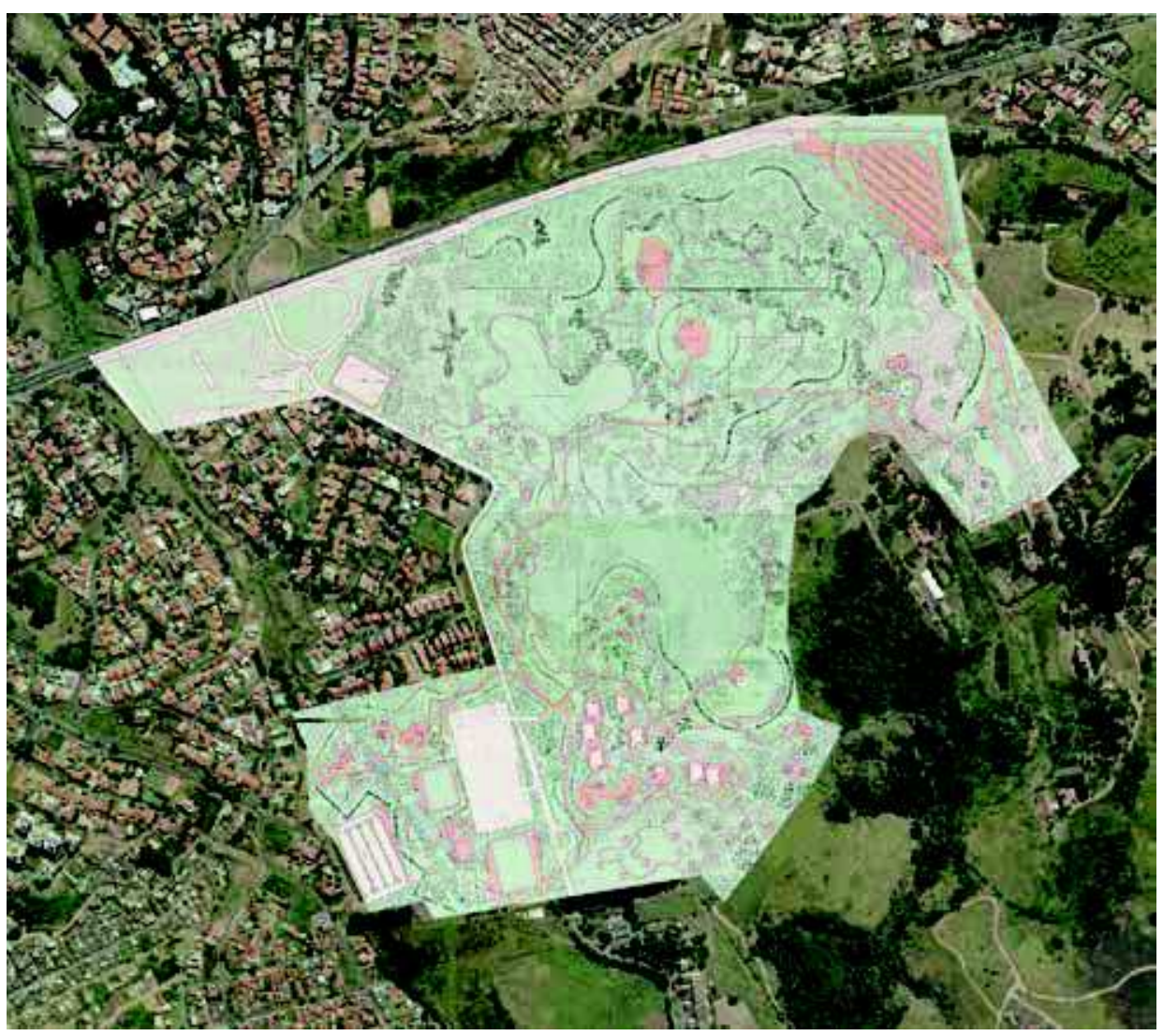

Figura 13 Projeto original fornecido pelo Escritório Burle Marx e montado sobre foto aérea Google Maps, 2015. Fonte: Escritório Burle Marx. Projeto de Roberto Burle Marx e Haruyoshi Ono. Desenho de Sônia, 1989. Projeto gráfico: Daniela Andrade Lacreta, setembro de 2015.

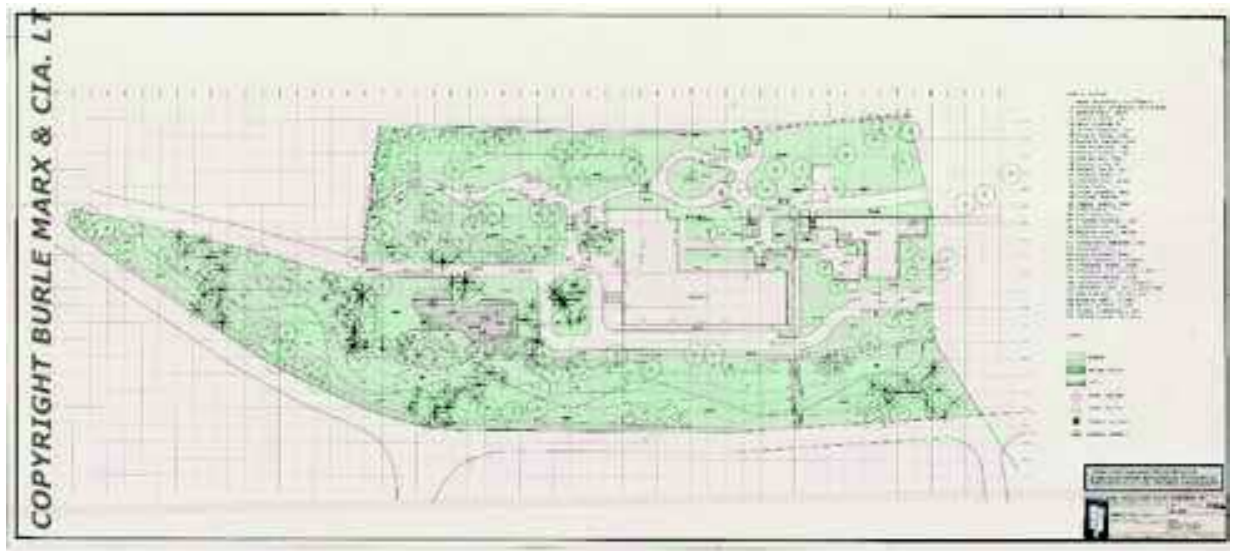

Figura 14 Projeto de Roberto Burle Marx e Haruyoshi Ono. Desenho de Sônia, 1989. 
Parque Ecológico Monsenhor Emílio José Salim, Campinas (SP): Contradições na Implementação de um Parque Urbano Contemporâneo

\section{CONSIDERAÇÕES SOBRE O FUNCIONAMENTO E A GESTÃO DO PARQUE AO LONGO DOS ANOS}

O Parque Ecológico Monsenhor Emílio José Salim permaneceu sob a administração do Governo Estadual de 1991, ano da sua inauguração, até 1995, quando passou a ser administrado por uma gestão compartilhada entre a Prefeitura Municipal de Campinas e a Secretaria Estadual do Meio Ambiente, convênio que durou até 2001. No período em que funcionou o convênio, o parque sofreu com a degradação, a falta de recursos e a gestão precária. O CIPAM foi extinto e a vigilância diminuída, ocasionando a depredação da infraestrutura e a destruição do sistema de energia elétrica. A extinção do projeto de educação ambiental acarretou a falta de manutenção do viveiro de plantas existente que, por sua vez, não forneceu mais as mudas para a reposição do paisagismo do parque, comprometendo o projeto. A paisagem, nesse ínterim, caracterizava-se pela invasão de gramíneas e o excesso de áreas áridas, causadas pela morte e não reposição das mudas.

Após alguns anos de funcionamento e com o declínio de suas atividades, em 2001, a Secretaria Estadual do Meio Ambiente anunciou a retomada total da administração do parque. De acordo com o órgão, uma verba emergencial para obras de manutenção do parque foi disponibilizada ${ }^{6}$, já que a prefeitura teria deixado de executar a manutenção do parque no período de sua gestão. $\bigcirc$ objetivo da secretaria, a partir desse momento, seria estabelecer parcerias com empresas privadas interessadas na recuperação e manutenção do parque, como já havia sido feito no Projeto Pomar em São Paulo. Esse projeto de recuperação foi orçado na época em $R \$ 4,9$ milhões $^{7}$ e tinha o intuito de recuperar, restaurar e manter o complexo arquitetônico (casarão, capela, anexo e tulha) tombado pelo Condephaat, como se pode observar na figura 15.

Em 2004, um Conselho de Orientação do Parque Ecológico é empossado com o intuito de acompanhar a implantação e a execução do novo Sistema de Gestão Compartilhada (estado e município), analisar o Plano de Trabalho e os Relatórios de Gestão de Controle, referendar o Regulamento Interno do Parque e suas possíveis alterações e sugerir projetos que não haviam sido contemplados no convênio. $\bigcirc$ projeto, então chamado "Projeto de Revitalização", contou com a participação das empresas parceiras Petróleo Brasileiro S.A (Petrobras), Companhia Paulista de Força e Luz (CPFL) e Shell do Brasil, responsáveis pela execução dos serviços e obras previstas - como cercamento da área do parque, reforma de lanchonetes, sanitários, portarias, ambulatório, equipamentos esportivos e de lazer, pavimentação e drenagem, equipamentos para a escola técnica de jardinagem e obras de paisagismo - dado que o projeto original de

Secretaria do Meio Ambiente lança livro com as pesquisas desenvolvidas em intervales. São Paulo Acontece: Secretaria do Meio Ambiente, 1 de abril de 2001. Disponível em: <http://www.ambiente.sp.gov.br/acontece/ noticias/secretaria-do-meio-ambiente-lanca-livro-com-as-pesquisas-desenvolvidas-em-intervales/>. Acesso em: 20 mar. 2014

7 SECRETARIA DO MEIO AMBIENTE DO ESTADO DE SÃO PAULO, 21 de julho de 2003. Disponível em: <http:// www.ambiente.sp.gov.br/acontece/noticias/alckmin-assina-protocolo-para-gestao-do-parque-ecologico-emcampinas/>. Acesso em: 20 mar. 2014. 
Burle Marx não havia sido instalado por completo. Para a Secretaria do Meio Ambiente, ficou designada a contratação de obras de infraestrutura, segurança e recuperação do complexo tombado. Já a prefeitura, se encarregaria de manter as áreas verdes do parque, fornecer serviços de vigilância interna, da preservação dos novos equipamentos instalados e da programação cultural e de lazer do parque.

\begin{tabular}{|c|c|}
\hline A. Hidráulica & $14.400,00$ \\
\hline B. Elétrica & $1.217 .650,00$ \\
\hline C. Pavimentação / Drenagem & $40.937,00$ \\
\hline D. Cercamento & $47.625,00$ \\
\hline E. Programação Visual & $59.375,00$ \\
\hline F. Lagos e cascatas & $414.275,00$ \\
\hline G. Paisagismo & $212.174,00$ \\
\hline H. Casarão/Museu $1920 \mathrm{~m} 2$ & $908.778,00$ \\
\hline I. Tulha/Auditónio & $386.288,00$ \\
\hline J. Restaurante $574 \mathrm{~m} 2$ & $143.500,00$ \\
\hline K. Lanchonetes ( 3 unidades $484 \mathrm{~m}$ ) & $121.500,00$ \\
\hline L. Sanitánios Públicos ( 5 unidades $253,40 \mathrm{~m}$ ) & $137.725,00$ \\
\hline M. Viveiro de Mudas ( $565 \mathrm{~m}$ ) & $141.250,00$ \\
\hline N. Portaria Principal ( $243 \mathrm{~m} 2)$ & $60.750,00$ \\
\hline O. Portaria Secundána $(195 \mathrm{~m} 2)$ & $48.750,00$ \\
\hline P. Administração e Ambulatóno $(150 \mathrm{~m} 2)$ & $37.500,00$ \\
\hline Q. Anfiteatro & $31.250,00$ \\
\hline R. Equipamentos esportivos e de lazer & $145.000,00$ \\
\hline S. Equipamentos novos & $556.875,00$ \\
\hline T.Transporte & $183.750,00$ \\
\hline TOTAL & R\$ 4.909.352,00 \\
\hline
\end{tabular}

Figura 15 Orçamento proposto para a revitalização do parque. Entre os custos mais altos estão a recuperação da parte elétrica do parque, a nova reforma do casarão e a implantação de novos equipamentos. Disponível em: <http:// www.ambiente.sp.gov.br/acontece/noticias/ alckmin-assina-protocolo-para-gestao-doparque-ecologico-em-campinas/>. Acesso em: 20 mar. 2014.

Em 2009, nova notícia ${ }^{8}$ é publicada, afirmando que uma nova recuperação no parque - principalmente do projeto paisagístico de Burle Marx e do restauro da sede da fazenda Mato Dentro - seria executada. $O$ restauro da casa sede coincidiu com a exposição de arquitetura e decoração Casa Cor, que aconteceu no conjunto histórico. Para a Secretaria do Meio Ambiente, a exposição trazia enorme valorização e prestígio ao parque.

Em maio de 2013, chegou ao fim, mais uma vez, a parceria estado/município na administração do parque. Fez-se um decreto que transferiu o parque por 99 anos ao município. Nessa época, o parque ficou novamente abandonado. A área sofria com a

8 FREGONESI, L. Revitalização e preservação no parque Monsenhor Emílio José Salim. São Paulo, Secretaria do Meio Ambiente, 25 de setembro de 2009. Disponível em: <http://www.ambiente.sp.gov.br/acontece/ noticias/revitalizacao-e-preservacao-no-parque-monsenhor-emilio-jose-salim/>. Acesso em: 20 mar. 2014. 
falta de manutenção e não recebia mais de quarenta visitantes nos dias de semana. As trilhas estavam intransitáveis; a sinalização, precária; o lago, sujo; os banheiros, inutilizáveis. Quadras poliesportivas ficaram tomadas por mato, e os jardins tomados por capivaras. Segundo reportagem ${ }^{9}$, embora a responsabilidade de manutenção fosse da prefeitura, a limpeza do parque não estava sendo realizada há quase um ano, o que, conforme o coordenador do parque, decorria de um problema de restrição orçamentária.

Em 2013, dois anos após a última reportagem apresentada, o parque ainda passa por dificuldades, não recebe muitos visitantes durante a semana e suas instalações estão inutilizadas por falta de manutenção. Ao longo dos anos, foi abandonado tanto pela população, quanto pelo poder público, embora diversas propostas de melhorias e revitalizações tenham sido apresentadas.

\section{AVALIAÇÃO DO PARQUE ENQUANTO EQUIPAMENTO PÚBLICO}

A ideia de que os parques públicos deveriam ser partes constituintes do ambiente urbano é uma das mais importantes contribuições do urbanismo do século XIX. Antes, ou os parques simplesmente não existiam nas cidades, ou eram reservados para o deleite de poucos. Em um momento em que o corpus disciplinar do urbanismo se estruturava, o consenso dos ideais progressistas de engenheiros, arquitetos, jardineiros e administradores era de que parques e jardins seriam elementos essenciais do espaço urbano, e quando combinados com os sistemas de vias largas e retilíneas, preferencialmente arborizadas, se constituiriam em instrumentos de cura para os males da cidade industrial. (HALL, 1997, p. 315).

No século XIX, as experiências pioneiras de ingleses e franceses constituem modelos para diversos planos em cidades na Europa e nas Américas. A partir do projeto de Nash para o Regent Park, em Londres, o desenho dos parques passa a ser integrado ao desenvolvimento da estrutura urbana, representando, em muitos casos, a valorização de áreas urbanas combinada à venda de lotes para novas edificações. A localização e o status social dos usuários determinavam o caráter do parque: os que se localizavam em bairros destinados a classes abastadas se distinguiam dos destinados às classes operárias. Na elaboração dos projetos, a combinação de elementos naturais, como topografia, vegetação e água, com outras estruturas - terraços, edifícios, pontes, fontes, espaços para jogos e concertos ao ar livre - poderia ser amplamente variada, de acordo com a escala e a localização do parque. Se a gama de soluções formais era diversificada, esses espaços tinham em comum a função de prover a cidade de áreas verdes e promover a educação estética e ética do cidadão. (HALL, 1997, p. 315).

Os parques urbanos contemporâneos ainda são criados com objetivos similares aos dos parques do século XVIII e XIX. O papel de equipamento estruturador do tecido

VERZIGNASSE, Rogério. Prefeitura de Campinas assumirá o Parque Ecológico em julho. Correio Popular, 24 abr. 2014. Disponível em: <http://correio.rac.com.br/_conteudo/2014/04/ig_paulista/170499-prefeitura-de-campinas-assumira-o-paque-ecologico-em-julho.html>. Acesso em: 25 abr. 2014. 
urbano e, principalmente, o de requalificação de áreas degradadas, agora com objetivos mais explícitos de valorização do território, aliam-se a novas questões de cunho ecológico, sustentável e de preservação do patrimônio ambiental. Cria-se marketing em torno das áreas verdes públicas como provedoras de qualidade de vida.

A característica mais definidora desse equipamento é a capacidade de abrigar um programa misto, onde contemplação e recreação se casam por meio de novas soluções espaciais elaboradas. (MACEDO; SAKATA, 2003, p. 43). Diversas áreas antigas e parques tradicionais são revisados e reformados para atender às novas demandas sociais, surgindo parques com novas características e novos programas, atributos estéticos e funcionais mais livres. (MACEDO; SAKATA, 2003, p. 47). Essas áreas abrigam projetos simplificados, e muitas vezes adaptados, envolvendo pouco investimento e resultados rápidos. A utilização de edifícios desabrigados e deteriorados para novos usos é comum, e grandes áreas abandonadas são transformadas em quadras, trilhas, playgrounds e áreas específicas para esportes cada vez mais diversificados. Os parques tornam-se peças chave da requalificação de ambientes degradados e da aceleração da transformação do território. Zonas produtivas obsoletas, linhas viárias e ferroviárias abandonadas e fragmentos de zonas rurais em meio às zonas urbanizadas são transformados em grandes parques.

O enfoque na questão ecológica e na preservação do patrimônio ambiental nos centros urbanos impulsiona a criação de novos parques a partir dos discursos ambientalistas vigentes. São delimitados, em todo o país, parques nacionais e estaduais, reservas ecológicas e áreas de proteção ambiental com novos programas de uso, que priorizam a preservação ecológica do local e a valorização dos aspectos rústicos da paisagem.

A partir do estudo da literatura recente sobre os parques brasileiros, levantaram-se questões que contribuem para a discussão dos problemas e potencialidades do Parque Ecológico Monsenhor Emílio José Salim. As questões abordadas são: localização e acessibilidade, projeto e programa e gestão.

\subsection{LOCALIZAÇÃO E ACESSIBILIDADE}

A acessibilidade e a proximidade são os elementos mais importantes para o público que frequenta parques urbanos, o que parece comprovar que os aspectos estéticos e históricos do lugar não são as razões principais para o seu sucesso. (SERPA, 2007, p. 76).

A instalação de grandes parques acarreta, quase sempre, rompimento com a malha viária, dificultando a possibilidade de articulação entre as vias. (MACEDO, 2012, p. 143). Por não serem pensados, na maioria dos casos, como sistemas de áreas verdes projetados em conjunto com os processos de urbanização das cidades, acabam por ocupar áreas que atendem a interesses imobiliários e de promoção política, com projetos desarticulados em relação às demandas da população e que contribuem para ocupação urbana dispersa e fragmentada. (MACEDO, 2012, p. 94).

Com o intuito de investir em parques que gerem visibilidade ao poder público, sem preocupação com a gestão do território e a infraestrutura, os parques brasilei- 
ros acabam tornando-se elementos dispensáveis em grande parte das ocasiões. Não existe avaliação quanto à necessidade do equipamento no local, ou às demandas da população que vive no entorno. Por estarem descolados das propostas urbanísticas das cidades, são "depositados" em terrenos vagos, que, na maioria das vezes, não possuem o menor potencial de lazer. Não são pensadas soluções viárias que facilitem o acesso, nem através do transporte público, nem com áreas adequadas para estacionamentos, ciclovias e acesso para pedestres.

É necessário que o parque urbano contemporâneo volte a ser pensado como elemento estruturador do espaço - não só fisicamente, mas como item indispensável para o lazer e a cultura da população. Há falta de integração entre os agentes produtores desses equipamentos. É necessária a multidisciplinaridade de especialistas, desde os gestores urbanos, passando por equipes técnicas (arquitetos, paisagistas, ecólogos, educadores, engenheiros) e, principalmente, a participação da população, para que os parques sejam equipamentos que acolham e promovam o lazer e a reunião, e não locais que segreguem e espantem os usuários.

Pode-se dizer que o Parque Ecológico Monsenhor Emilio José Salim é um divisor de duas regiões com realidades bem diferentes. Ao redor da portaria principal, localizada às margens da rodovia Heitor Penteado, estão os condomínios mais nobres da cidade. Junto a outra portaria, localizada na avenida Manoel Afonso Ferreira, no Jardim São Fernando, estão distribuídas casas de alto padrão, mas há também grande concentração de loteamentos clandestinos e favelas. A realidade da utilização do parque segue a mesma ordem. É nítida a diferenciação dos usuários nos dois polos.

$\mathrm{Na}$ área da portaria principal, poucos usuários praticam caminhadas e exercícios. Não se veem pessoas sozinhas, somente grupos que se reúnem para caminhar, achando que assim estarão mais protegidos. Também há grupos que percorrem as trilhas para a prática de mountain bike, com suas bicicletas caras, na pista implantada recentemente. Já na área das quadras poliesportivas, próximo à portaria secundária, são encontrados garotos descalços empinando pipas ou grupos de homens jogando futebol nos campinhos, que mais se assemelham às peladas nas várzeas. Existe uma distinção social muito clara entre os usuários do parque, e a linha invisível que divide essas territorialidades distintas é percebida facilmente.

O parque só é acessado de carro ou de ônibus. Como sua portaria principal localiza-se numa rodovia movimentada, torna-se praticamente impossível chegar a pé ou de bicicleta, pois não existem ciclovias e faixas de pedestre que facilitem o acesso. Na tabela 3, é possível ver as opções de transporte público fornecidas para o Parque Ecológico Monsenhor Emílio José Salim em comparação ao Parque Portugal. Além de contar com quantidade menor de linhas, apenas uma delas (3.97 Gramado/Circular Centro) vem de outras regiões de Campinas. As demais linhas são provenientes dos bairros do entorno e dos distritos de Sousas e Joaquim Egídio. A mesma tabela, com as linhas que atendem o Parque Portugal, demonstra que as opções são maiores e atendem diversos bairros distantes, principalmente aqueles em que a população tem renda média baixa. 
Tabela 3 Rotas de Ônibus Oferecidas pela Cidade de Campinas para o Parque Portugal e o Parque Ecológico Monsenhor Emílio José Salim

\begin{tabular}{l}
\hline \multicolumn{1}{c}{ Parque Ecológico Monsenhor Emílio José Salim } \\
\hline$-3.90-$ Joaquim Egídio Via Sousas \\
\hline$-3.91-$ Nova Sousas \\
\hline$-3.92-$ San Conrado \\
\hline$-3.95-$ Notre Dame \\
\hline$-3.96-$ Sousas \\
\hline$-3.97-$ Gramado/Circular Centro \\
\hline Lagoa do Taquaral (Parque Portugal) \\
\hline$-1.71-$ Campinas Shopping / Shopping Dom Pedro \\
\hline-2.30 - Ipaussurama \\
\hline$-2.49-$ Jardim Flamboyant / Parque dos Eucaliptos \\
\hline$-3.32-$ Terminal Barão Geraldo / Hospital das Clínicas \\
\hline-3.38 - Terminal Barão Geraldo/Shopping Dom Pedro/Shopping Iguatemi \\
\hline-3.45 - Jardim Carlos Lourenço / Estação Cidade Judiciária \\
\hline-3.48 - Vila Marieta / Estação Cidade Judiciária \\
\hline$-3.51-$ PUCC Primavera \\
\hline-3.57 - PUCC - Jardim Santana \\
\hline-3.59 - Jardim Esmeraldina/Cidade Judiciária \\
\hline-3.62 - Parque Brasília I/Via Taquaral \\
\hline-3.69 - Parque Imperador/Vila 31 de março
\end{tabular}

Fonte: Disponível em: <http://www.campinas.sp.gov.br/noticias-integra.php?id=1833>. Acesso em: 20 jul. 2015.

\subsection{PROJETO E PROGRAMA}

Embora a criação de parques urbanos tenha aumentado nos últimos trinta anos, não se pode dizer o mesmo em relação à qualidade dos projetos desenvolvidos. Seja por falta de planejamento adequado ou por amadorismo técnico, a verdade é que a maioria dos parques produzidos carece de qualidade de projeto e apresenta programas falhos. (MACEDO; SAKATA, 2003, p. 55). São projetos simples, apenas adaptando antigas áreas abandonadas para os novos usos. Com o objetivo de manter custos baixos e propiciar uso imediato, são instalados poucos equipamentos, alguns brinquedos e simples trilhas para caminhada. Poucos são os casos nos quais o projeto é cuidadosamente desenvolvido, focando na necessidade da população e na qualidade do espaço. (MACEDO; SAKATA, 2003, p. 48).

A implantação desses parques também favorece a pouca qualidade do equipamento. Muitas vezes, a administração pública responsável pela gestão do parque não tem verba suficiente para total implantação do mesmo, fazendo a obra em etapas que, 
na maioria das vezes, demoram anos para serem concluídas, ou cortando projetos de quadras, banheiros e paisagismo para diminuir custos e implantá-lo mais rapidamente. O desfecho são parques incompletos, que não atendem às demandas da população e poucos atrativos possuem.

Em alguns casos, os projetos voltam-se apenas para o interesse imobiliário, não visam ao atendimento das reais demandas dos usuários. São parques descolados da realidade, que não beneficiam a comunidade da região onde estão inseridos. Por mais belos e imponentes que sejam, pecam na artificialidade e na generalização de usos, pois, na sua concepção, faltaram análises substanciais, que poderiam revelar os interesses dos usuários. Como esses projetos partem de concepção meramente formalista, oprimem o usuário, não causam interesse e nem curiosidade. (SERPA, 2007, p. 45).

O Parque Ecológico Monsenhor Emílio José Salim encontra-se, em 2015, inseguro, sem atrativos esportivos e culturais e mal sinalizado. Embora o programa inicial tivesse grande poder atrativo, contando com museu, restaurante, bar, quadras, mirante, espaço de estar e festas, vistas panorâmicas e promoção de espaço educativo ambiental, o parque conta somente com trilhas para bicicletas, algumas quadras em condição de uso e espaços vazios tomados pelo mato, não havendo atrativos para frequência estável de usuários. Os edifícios abandonados causam opressão e medo, e a prática de caminhada pelas trilhas gera desconforto e insegurança. Na figura 16 estão localizadas as principais atrações do parque e fotos de 2015 de seus pontos principais.

A intenção inicial de focar nas questões ecológicas, fazendo-o por meio da criação do CIPAM, caracterizava o parque como alternativa cultural interessante, porém desde o fechamento do CIPAM não existem motivos para visitar o parque. Os edifícios que antes abrigavam o restaurante e o ripado são extremamente interessantes, porém, como todos os demais equipamentos, estão abandonados. À beira do lago, proveem sombra e uma bela vista, podendo ser utilizados de diversas maneiras. Já as edificações que abrigavam banheiros e lanchonetes, encontram-se em ruínas, pichadas e sujas em meio ao matagal. As figuras 17 a 19 apresentam o estado em que se encontravam os equipamentos do parque em 2015.

Comparando o projeto original, obtido no Escritório Burle Marx, com o que existe hoje no parque, ficou clara a distinção entre o que foi projetado e o que foi de fato executado. Apenas parte do projeto paisagístico, tão importante para o sucesso do parque, foi instalado; a maioria dos maciços de árvores, que proveriam sombra e ambiente agradável, não foi implantada. Somente as fileiras de palmeiras e duas áreas de matas e árvores de grande porte, previstas no projeto, foram instaladas. A comparação evidencia que o projeto do parque não foi implantado por completo.

\subsection{GESTÃO}

Entre os problemas mais comuns que afligem os grandes parques urbanos, é possível citar a falta de políticas de gestão que sejam independentes do governante no momento. (MATIELLO, 2001). Em geral, parques estaduais têm porte maior em relação 
a parques municipais. Nestes, a ação municipal é mais direta e objetiva, garantindo a qualidade do espaço, mantendo viveiros e infraestrutura em bom estado. Já os parques estaduais evidenciam má gestão, permanecendo diversas vezes e por longos períodos abandonados. Mesmo os parques situados em áreas nobres da cidade apresentam esse quadro de "insuficiência crônica". (MACEDO; SAKATA, 2003, p. 54).
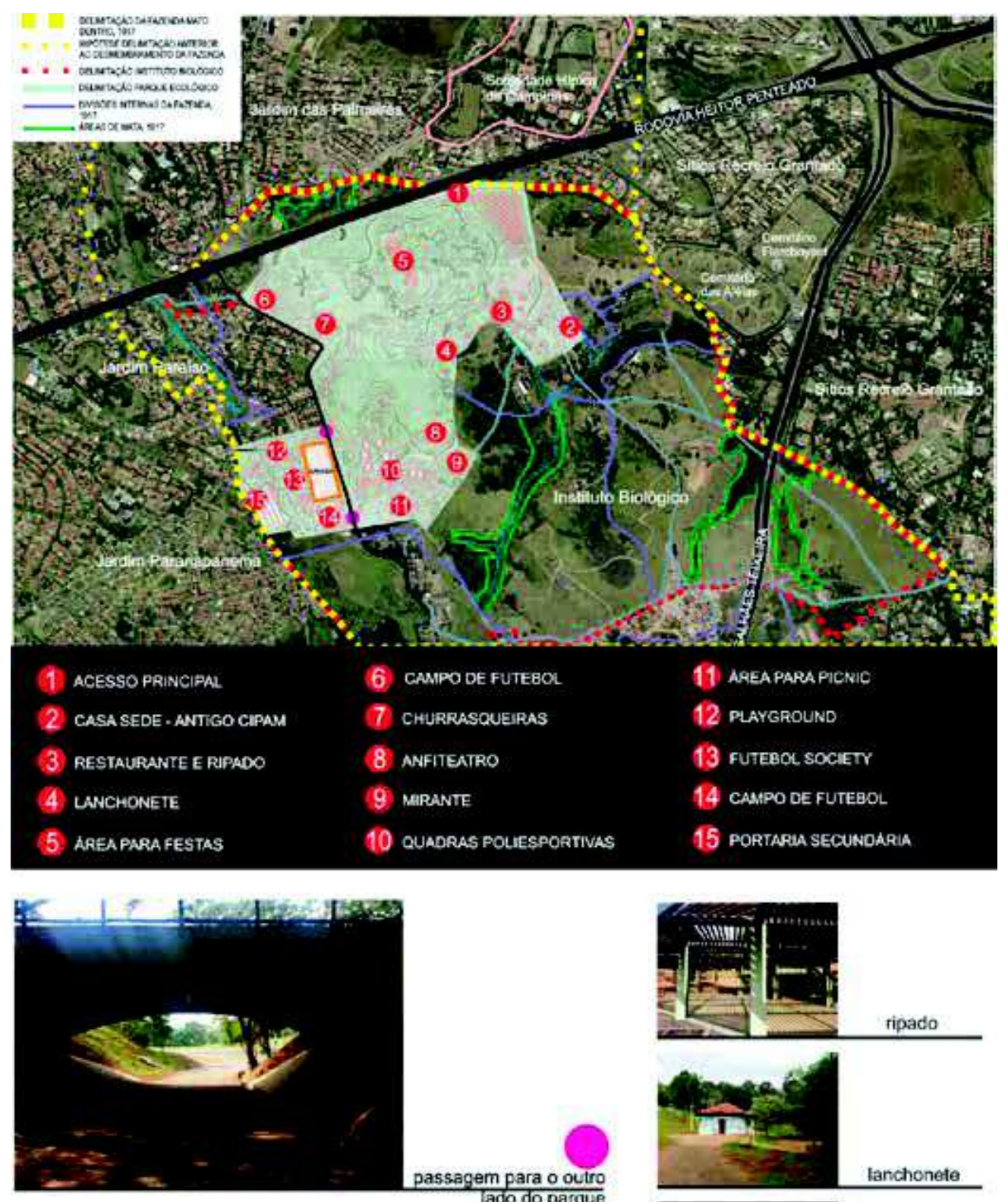

o parque é cortado em nivel pela avenida que dá acesso à Estaçĕo da SANASA sendo que o ecesso de um lado para outro do parque e ferto par duaspassagens conforme a foto acima

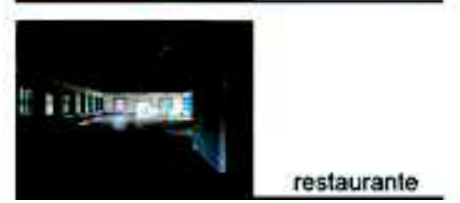

Figura 16 Projeto paisagístico original, localização das principais atrações do parque e fotos de seus pontos principais, 2015.

Projeto gráfico: Daniela Andrade Lacreta, 2015. 
Parque Ecológico Monsenhor Emílio José Salim, Campinas (SP): Contradições na Implementação de um Parque Urbano Contemporâneo

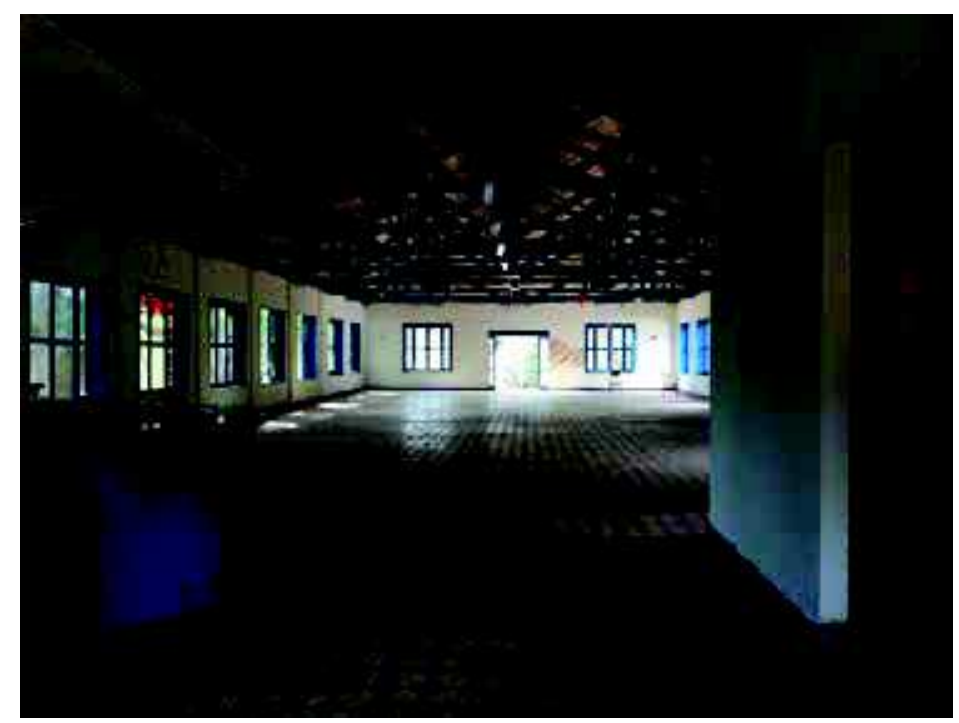

Figura 17 Antigo estábulo que funcionou por um período como restaurante, e, até a data da visita, encontrava-se abandonado.

Foto: Daniela Andrade Lacreta, 11 jul. 2015.

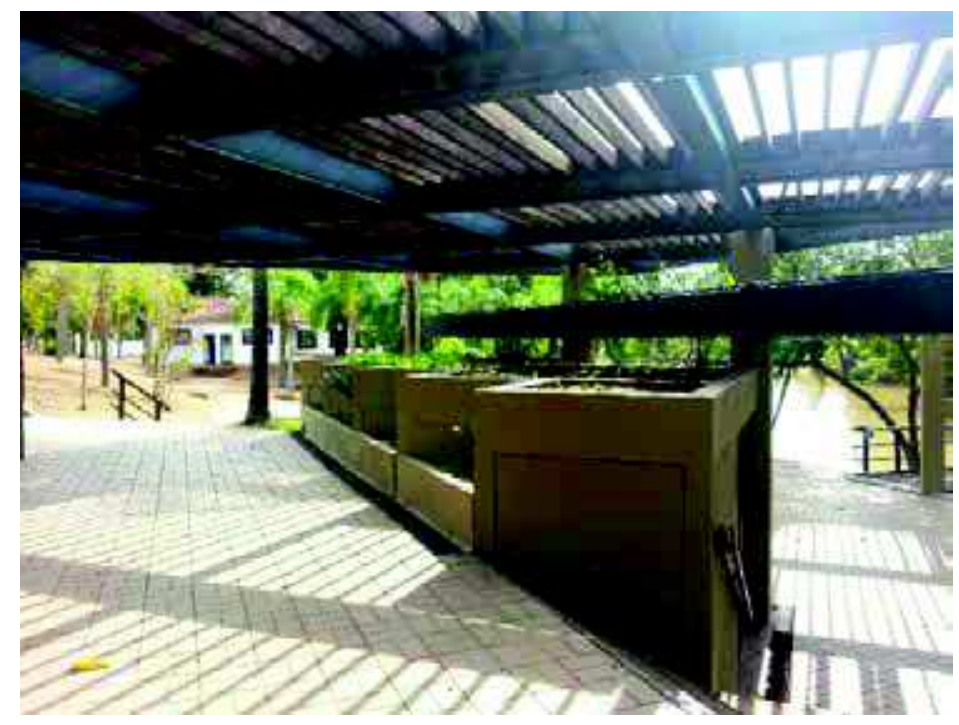

Figura 18 Ripado. Projetado pelo Escritório Burle Marx para espaço de exposição e lojas, e, até a data da visita, também se encontrava abandonado.

Foto: Daniela Andrade Lacreta, 11 jul. 2015.

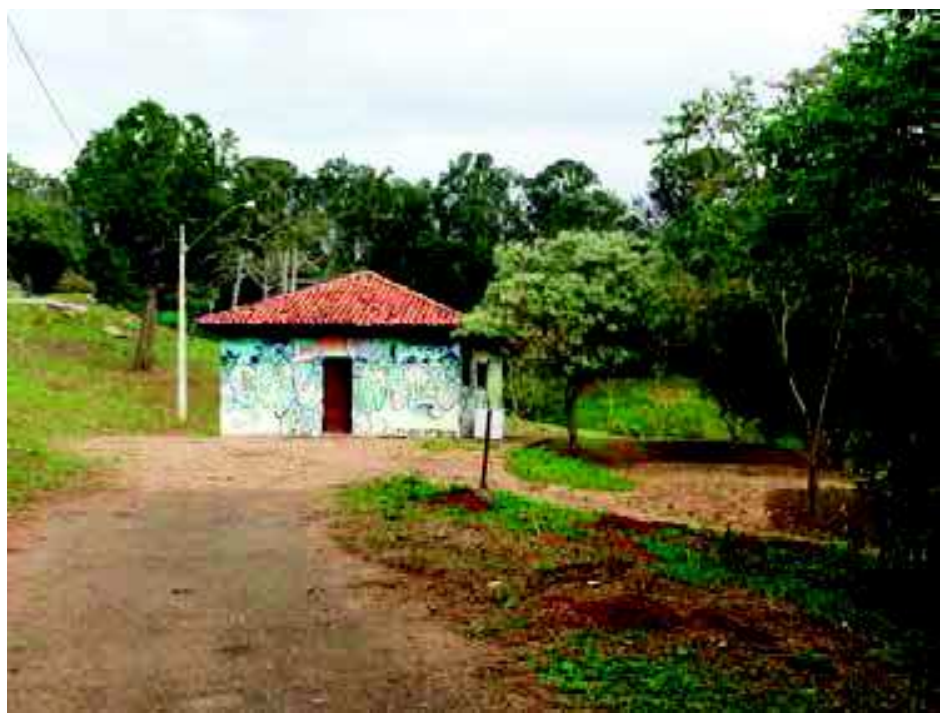

Figura 19 Lanchonete.

Foto: Daniela Andrade Lacreta, 11 jul. 2015. 
É preciso que a gestão dos parques urbanos seja elaborada de forma a ser mais autossustentável e participativa, em que agentes públicos, população e parcerias empresariais possam se envolver nas decisões relacionadas à administração e ao modo de utilização mais adequado para a realidade da comunidade usuária. (MATIELLO, 2001).

A partir dos trabalhos de Macedo e Sakata (2003) e Serpa (2007), e também utilizando a avaliação da sustentabilidade social no planejamento e gestão dos parques elaborada por Matiello (2001), podem-se elencar as principais fragilidades características dos parques urbanos contemporâneos. A monofuncionalidade (MATIELLO, 2001) - traduzida pela característica meramente ornamental e de imagem do poder público - isola o homem do espaço. É a natureza operacionalizada e manipulada que prioriza as formas, em detrimento dos conteúdos sociais. (SERPA, 2007). Há carência de interdisciplinaridade nas equipes envolvidas na produção desses equipamentos, 0 que resulta no privilégio dos interesses do poder público e do mercado imobiliário, produzindo espaços que atendem somente às demandas financeiras e à visibilidade dos empreendimentos, negligenciando a qualidade dos equipamentos.

A falta de parcerias adequadas na gestão dos parques transforma-os em grandes fardos para os gestores públicos. Existem diversos casos, no exterior, onde os parques urbanos possuem gestão compartilhada entre poder público e empresas privadas, com ativa participação da população, que faz doações generosas para a manutenção dos espaços. Restaurantes, lojas, feiras, espaço para eventos e cursos estão entre as fontes de renda desses equipamentos, que auxiliam na manutenção de jardins, quadras e infraestrutura e atraem a população. Os usuários se sentem parte importante e responsável pelo espaço que utilizam, e é quase raro encontrar parques abandonados e depredados.

Serpa (2007) defende que a soma dos processos de apropriação de um coletivo de indivíduos não é suficiente para legitimar a noção de espaço público. O parque público é um espaço aberto à população, acessível a todos, posto à disposição dos usuários, mas essas características não são suficientes para defini-lo como espaço público. Esse processo, por um lado, é o resultado da concepção (e da promoção) do parque público como cenário destinado à fascinação dos futuros usuários, transformando-o em uma espécie de imagem publicitária das administrações locais, sem nenhuma continuidade de práticas sociais que pudessem oferecer algum conteúdo e significado. (ARANTES, 1998 apud SERPA, 2007, p. 37).

A partir do levantamento histórico sobre a instalação e funcionamento do Parque Ecológico Monsenhor Emílio José Salim, pode-se constatar o quanto sua implantação foi determinante para a promoção imobiliária de uma área nobre da cidade. Após sua inauguração, no início da década de 1990, os bairros da região leste, como já visto, consolidaram-se e se valorizaram.

Do ponto de vista da gestão, é possível observar que, enquanto os governos municipal e estadual pertenciam a um mesmo grupo político partidário (na época de sua instalação), o parque manteve administração estável e houve investimento para a implantação de parte de seus equipamentos. $O$ parque funcionou plenamente duran- 
Parque Ecológico Monsenhor Emílio José Salim, Campinas (SP): Contradições na Implementação de um Parque Urbano Contemporâneo

te pouco tempo. Já no período em que prefeitura municipal e governo estadual não pertenciam a mesma legenda, foi abandonado.

A despeito da execução parcial do seu projeto e programa, que acarretou problemas de uso como caminhos interrompidos, dificuldade de acesso entre os setores, grandes áreas vazias, pouca sombra, falta de banheiros, bebedouros, bancos, e das questões relacionadas à localização e acessibilidade (figura 20) - grande distância dos bairros carentes de espaços verdes, acesso feito quase exclusivamente por carro -, a escassa utilização do parque agravou-se pelos problemas de gestão do equipamento.

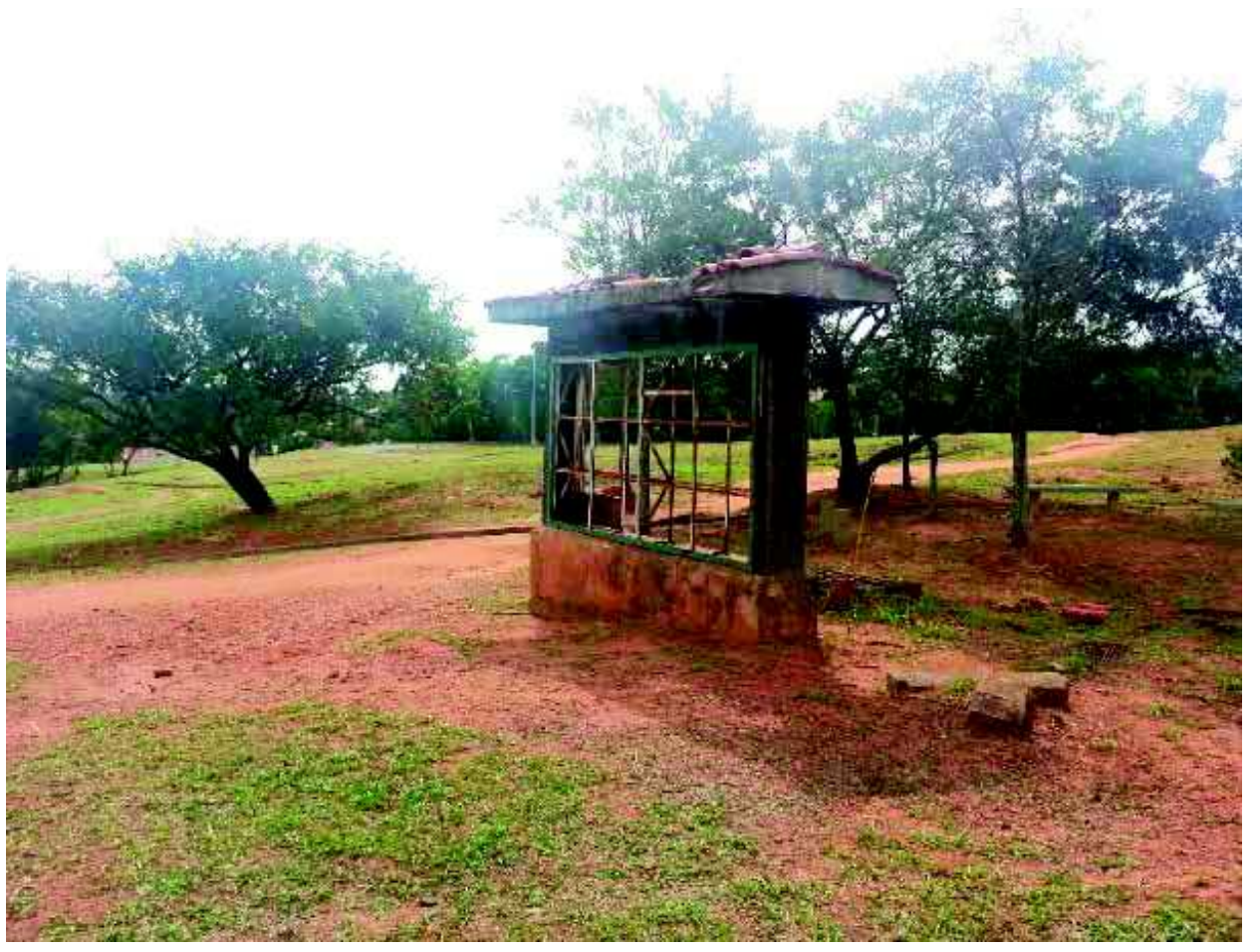

Figura 20 Antigo totem informativo na segunda portaria do parque. Nota-se a falta de caminhos para o acesso aos equipamentos do local.

Foto: Daniela Andrade Lacreta, 11 jul. 2015.

Administrado de forma compartilhada pelo Governo do Estado de São Paulo e a Prefeitura Municipal de Campinas, nos seus primeiros anos, o parque recebeu pouca verba para investimento em programas culturais e manutenção do que havia sido instalado inicialmente. $O$ problema já teve início na implantação do equipamento, que, conforme levantado, não contempla todo o projeto paisagístico proposto e nem a infraestrutura. Ao longo dos anos, faltou uma administração presente, que se dedicasse exclusivamente ao parque, o que se observou com o declínio das atividades promovidas e o fechamento de seus espaços.

Segundo diagnóstico feito pela Secretaria do Verde e Meio Ambiente Sustentável da Prefeitura de Campinas (2015), como subsídio para a elaboração do Plano Municipal do Verde, o Parque Ecológico, mesmo sendo o de maior área, não é lembrado 
pelos entrevistados como um dos principais da cidade. Entre os principais motivos dos entrevistados para frequentar um parque, estão o esporte, a socialização e o ambiente agradável. A pesquisa demonstrou que a gestão atual do Parque Ecológico não atende a essas demandas da população de Campinas.

Conforme os gráficos (figuras 21 a 24) elaborados a partir de Oficinas Participativas promovidas pela Secretaria Municipal do Verde, Meio Ambiente e Desenvolvimento Sustentável (SVDS), em 2015, como parte do Diagnóstico Preliminar para o Plano Municipal do Verde, fica claro que o Parque Ecológico não figura entre os parques mais frequentados da cidade, sendo a principal razão citada a falta de estrutura, de manutenção e de segurança.

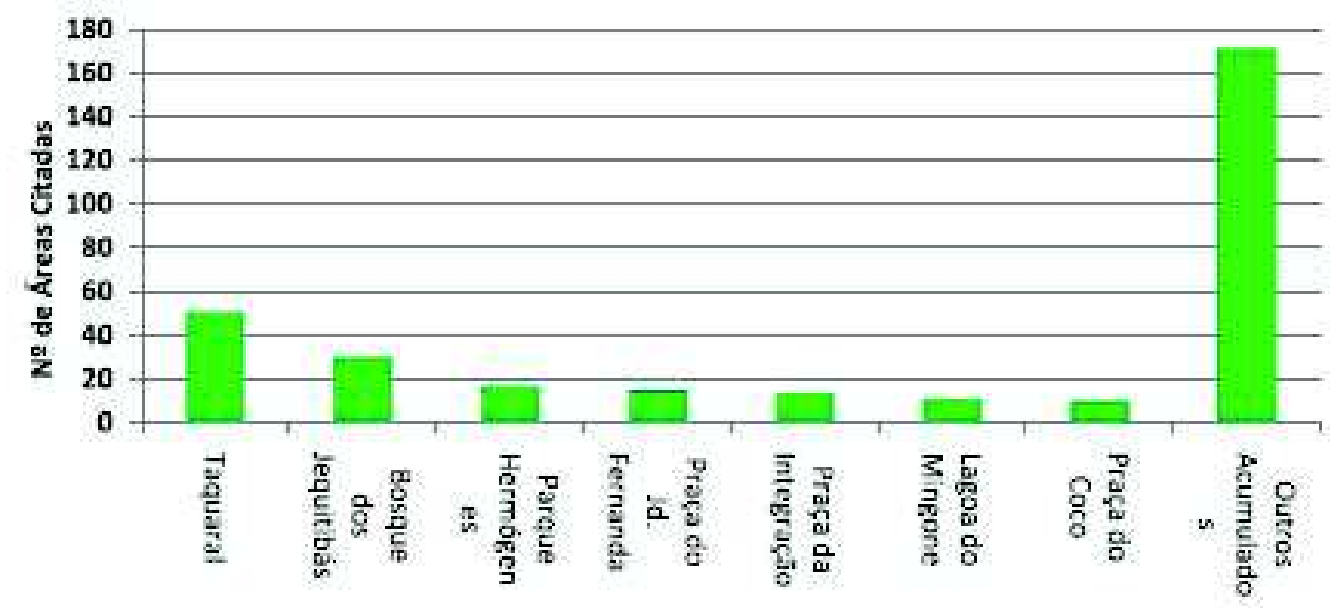

Figura 21 Relação das principais áreas verdes frequentadas na cidade - citadas nas Oficinas Participativas, promovidas pela Secretaria do Verde, como parte do Plano Municipal do Verde.

Fonte: Diagnóstico Preliminar SDVS/PMC, 2015. Disponível em: <http://campinas.sp.gov.br/arquivos/meioambiente/diagnostico_preliminar.pdf > . Acesso em: 20 de jul. 2015.

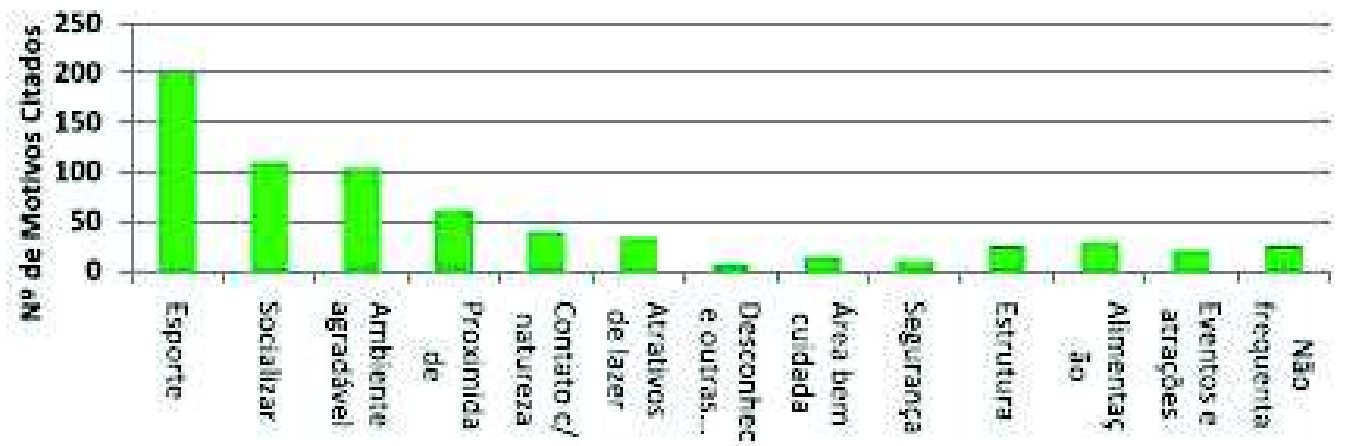

Figura 22 Relação dos principais motivos para frequentar as áreas verdes na cidade - citadas nas Oficinas Participativas promovidas pela Secretaria do Verde como parte do Plano Municipal do Verde.

Fonte: Diagnóstico Preliminar SDVS/PMC, 2015. Disponível em: <http://campinas.sp.gov.br/arquivos/meioambiente/diagnostico preliminar.pdf>. Acesso em: 20 de jul. 2015. 
Parque Ecológico Monsenhor Emílio José Salim, Campinas (SP): Contradições na Implementação de um Parque Urbano Contemporâneo

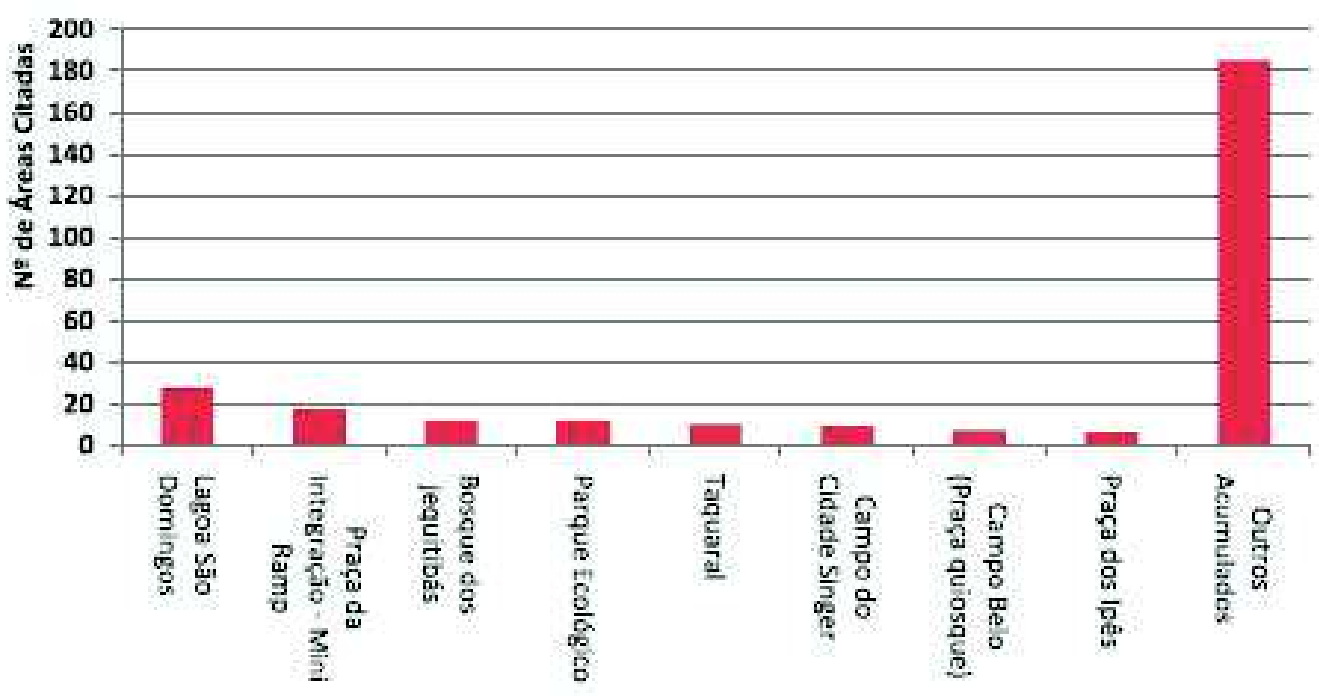

Figura 23 Relação das principais áreas verdes não frequentadas - citadas nas Oficinas Participativas promovidas pela Secretaria do Verde como parte do Plano Municipal do Verde.

Fonte: Diagnóstico Preliminar SDVS/PMC, 2015. Disponível em: <http://campinas.sp.gov.br/arquivos/meioambiente/diagnostico_preliminar.pdf>. Acesso em: 20 de jul. 2015.

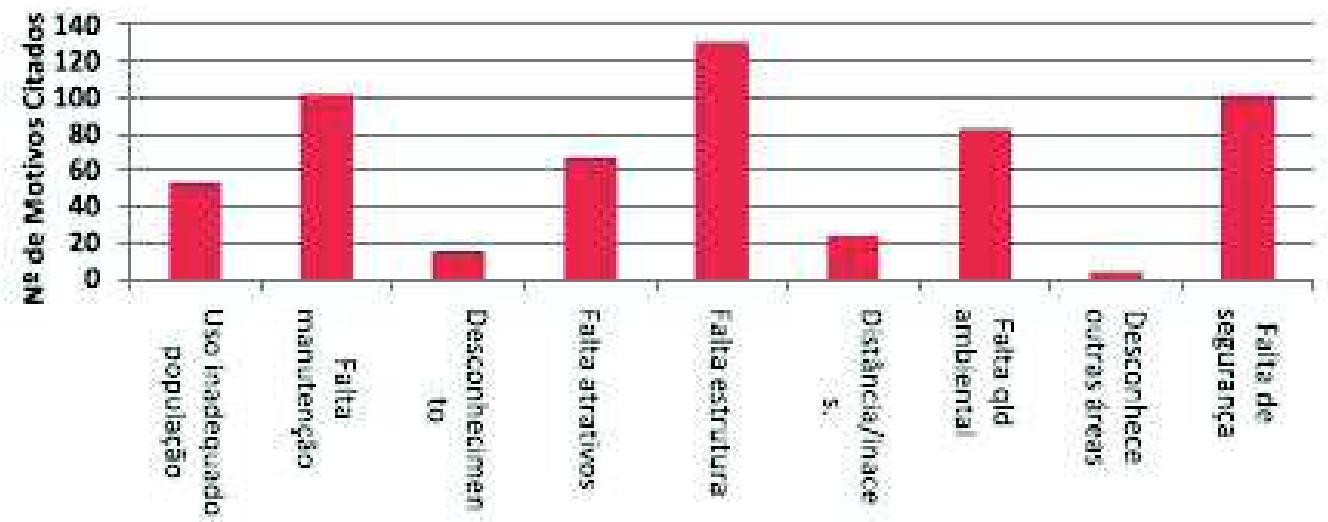

Figura 24 Relação dos principais motivos para não frequentar as áreas - citados nas Oficinas Participativas promovidas pela Secretaria do Verde como parte do Plano Municipal do Verde.

Fonte: Diagnóstico Preliminar SDVS/PMC, 2015. Disponível em: < http://campinas.sp.gov.br/arquivos/meioambiente/diagnostico_preliminar.pdf>. Acesso em: 20 de jul. 2015.

\section{CONSIDERAÇÕES FINAIS}

Esta pesquisa demonstrou que, além de atender às demandas de espaços de lazer para a cidade de Campinas e a certo modismo que ampliou a instalação de parques ecológicos por todo o país - fruto da emergência das questões ambientais a partir da década de 1970 -, a instalação do Parque Ecológico Monsenhor Emílio José Salim também foi pautada por interesses imobiliários e de promoção de grupos políticos. 
Embora a escolha do local justifique-se, pela preservação e incorporação ao programa do parque de um conjunto arquitetônico de valor patrimonial, esta também se revela como uma escolha interessada, no sentido de garantir a baixa densidade de ocupação e a qualidade paisagística de uma região da cidade visada pelo mercado imobiliário de alta renda. A instalação do parque coincide com a consolidação de loteamentos fechados e condomínios horizontais de alto padrão na região leste de Campinas.

A análise do projeto e dos mapas da fazenda demonstrou que a maioria dos edifícios do complexo cafeeiro foi aproveitada para abrigar novos usos, e os antigos caminhos que ligavam as áreas de plantio foram transformados em caminhos principais do parque. $\bigcirc$ projeto original previa o plantio de espécies nativas da região de Campinas, combinado à vegetação exótica, que traria cor e sombra para os diversos pontos de permanência, mas foi instalado apenas em parte. Consequentemente, o sentido de uma área verde, densa e agradável e com canteiros sinuosos, característicos da obra de Burle Marx, não se concretizou.

O parque carece de uma personalidade que o torne atrativo para toda a cidade, como o CIPAM - instalado na casa sede da fazenda e desativado logo após a inauguração - com um programa contemporâneo que abranja cultura, educação e lazer. Embora localizado em área de difícil acesso, esse não é o motivo para seu fracasso. Com a promoção de transporte público e um programa adequado de atividades, o parque atrairia visitantes de diversas partes da cidade.

\title{
REFERÊNCIAS BIBLIOGRÁFICAS
}

\author{
Antigo casarão da "Mato Dentro" será restaurado. Correio Popular, Campinas, 24 set. 1988. \\ BADARÓ, R. de S. C. Campinas: o despontar da modernidade. Campinas: CMU/UNICAMP, 1996. 162 p. \\ BITTENCOURT, Luiz Cláudio. Campinas Centro Histórico: rupturas e (des)continuidades. Oculum Ensaios, n. \\ 2, jan. 2002, Campinas: Programa de Pós-Graduação em Urbanismo da Pontifícia Universidade Católica de \\ Campinas. (PUC-Campinas), p.131-139. \\ Começa a preservação da fazenda. Correio Popular, Campinas, 24 de setembro de 1988. \\ Espaços para educação ambiental. Correio Popular, Campinas, 24 de junho de 1990. \\ Especialistas consideram a obra pioneira. Correio Popular, Campinas, 24 de junho de 1990. \\ FAVARO, T. Objetivo do projeto é integrar os jovens ao meio ambiente. Correio Popular, Campinas, 14 de \\ dezembro de 2003.
}

FREGONESI, L. Revitalização e preservação no Parque Monsenhor Emílio José Salim. São Paulo, Secretaria do Meio Ambiente, 25 set. 2009. Disponível em: < http://www.ambiente.sp.gov.br/acontece/noticias/revitalizacaoe-preservacao-no-parque-monsenhor-emilio-jose-salim/>. Acesso em: 20 mar. 2014.

HALL, P. Cidades do amanhã: uma história intelectual do planejamento e do projeto urbano nos séculos urbanos no século XX. São Paulo: Perspectiva, 1997. 550 p. Coleção Estudos.

LIMA, Siomara Barbosa Stroppa de. Os jardins de Campinas: o surgimento de uma nova cidade (1850-1935).

2000. 179 f. Dissertação (Mestrado em Urbanismo) - Faculdade de Arquitetura e Urbanismo da Pontifícia Universidade Católica de Campinas, Campinas, 2000.

MACEDO, Silvio Soares. Paisagismo brasileiro na virada do século: 1990-2010. São Paulo: Edusp, Campinas: Unicamp, 2012.

; SAKATA, Francine Gramacho. Parques urbanos no Brasil. 2 ed., São Paulo: Edusp, 2003. 
Parque Ecológico Monsenhor Emílio José Salim, Campinas (SP): Contradições na Implementação de um Parque Urbano Contemporâneo

MARTINS, J. P. Iniciativa privada salva parque ecológico. Correio Popular, Campinas, 2008.

MATIELLO, Alexandre M. A sustentabilidade no planejamento e gestão de parques urbanos em Curitiba - PR. Uma Questão Paradigmática? 2001. 301 f. Dissertação (Mestrado em Sociologia Política) - Universidade Federal de Santa Catarina, Florianópolis, 2001.

Mato Dentro foi transformada em parque ecológico. Correio Popular, Campinas, 14 de julho de 1989.

PREFEITURA DE CAMPINAS. Plano Diretor, 1991. Disponível em: <http://www.campinas.sp.gov.br/governo/ seplama/plano-diretor-2006/>. Acesso em: mai. 2015.

Lei Complementar n 15 de 27 de Dezembro de 2006. Dispõe sobre o Plano Diretor, Campinas, 2006.

Disponível em: <http://www.campinas.sp.gov.br/governo/seplama/plano-diretor-2006/>. Acesso em: mai. 2015.

Plano Diretor. Revisão 2006. Disponível em: <http://www.campinas.sp.gov.br/governo/seplama/planodiretor-2006/>. Acesso em: mai. 2015.

Diagnóstico Preliminar - Plano Municipal do Verde, 2015. Secretaria Municipal do Verde, Meio Ambiente e Desenvolvimento Sustentável (SVDS), 2015. Disponível em: < http://campinas.sp.gov.br/governo/meioambiente/plano_municipal_verde.php>. Acesso em: 15 set. 2015.

Projeto para o meio ambiente é lançado no Parque Ecológico. Correio Popular, Campinas, 27 de setembro de 1996.

O resgate da história na fazenda Mato Dentro. Correio Popular, Campinas, 24 de junho de 1990.

SANTOS, A. C. Campinas, das origens ao futuro: compra e venda de terras e águas e um tombamento na primeira sesmaria da Freguesia de Nossa Senhora da Conceição das Campinas do Mato Grosso de Jundiaí. Campinas: Unicamp, 2002.

SÃO PAULO (Estado). Decreto n 27.071, de 8 de junho de 1987. Cria o Parque Ecológico Monsenhor Emílio José Salim e dá providências correlatas. Disponível em: <http://governo-sp.jurisbrasil.com.br/legislação/190352/ decreto-27071-87>.

. Decreto $n^{\circ} 32.478$, de 26 de outubro de 1990. Estabelece diretrizes para a implantação e a administração do Parque Ecológico Monsenhor Emílio José Salim. Disponível em: < http://governo-sp.jurisbrasil.com.br/ legislação/183732/decreto-32478-90>.

Secretaria do Meio Ambiente lança livro com as pesquisas desenvolvidas em intervales. São Paulo Acontece: Secretaria do Meio Ambiente, 1 de abril de 2001. Disponível em: <http://www.ambiente.sp.gov.br/acontece/ noticias/secretaria-do-meio-ambiente-lanca-livro-com-as-pesquisas-desenvolvidas-em-intervales/>. Acesso em: 20 mar. 2014.

SECRETARIA DO MEIO AMBIENTE. Alckmin assina protocolo para gestão do Parque Ecológico em

Campinas. São Paulo, 21 jul. 2003. Disponível em: <http://www.ambiente.sp.gov.br/acontece/noticias/alckminassina-protocolo-para-gestao-do-parque-ecologico-em-campinas/3/>. Acesso em: 25 abr. 2014.

SERENZA, E. Secretaria do Meio Ambiente Lança Livro com as Pesquisas Desenvolvidas em Intervales. São Paulo Acontece: Secretaria do Meio Ambiente, 1 de abril de 2001. Disponível em: <http://www.ambiente.sp.gov. $\mathrm{br} / a c o n t e c e / n o t i c i a s / s e c r e t a r i a-d o-m e i o-a m b i e n t e-l a n c a-l i v r o-c o m-a s-p e s q u i s a s-d e s e n v o l v i d a s-e m-i n t e r v a l e s />$.

SERPA, A. O espaço público na cidade contemporânea. São Paulo: Contexto, 2007.

SILVA, A. P. Engenhos e fazendas de café em Campinas (séc. XVII-XX). Anais do Museu Paulista: História e Cultura Material, vol. 14, n. I, jan/jun, 2006.

SILVA, Paula Francisca Ferreira da. A expansão urbana de Campinas através de condomínios e loteamentos fechados (1974-2005). 2008. 163 f. Dissertação (Mestrado em Arquitetura e Urbanismo) - Escola de Engenharia de São Carlos - Universidade de São Paulo, São Carlos, 2008.

VERZIGNASSE, Rogério. Prefeitura de Campinas assumirá o Parque Ecológico em julho. Correio Popular, 24 abr. 2014. Disponível em: <http://correio.rac.com.br/_conteudo/2014/04/ig_paulista/170499-prefeitura-decampinas-assumira-o-paque-ecologico-em-julho.html>- Acesso em: 25 abr. 2014.

Nota do editor

Submissão: 25 mai. 2015

Aprovação: 23 out. 2015 